\title{
BIAXIAL CREEP-FATIGUE BEHAVIOR OF TYPE 316H STAINLESS STEEL TUBE
}

\author{
by
}

S. Majumdar

ARGONNE NATIONAL LABORATORY, ARGONNE, ILLINOIS

Prepared for the U. S. DEPARTMENT OF ENERGY under Contract W-31-109-Eng-38 


\section{DISCLAIMER}

This report was prepared as an account of work sponsored by an agency of the United States Government. Neither the United States Government nor any agency Thereof, nor any of their employees, makes any warranty, express or implied, or assumes any legal liability or responsibility for the accuracy, completeness, or usefulness of any information, apparatus, product, or process disclosed, or represents that its use would not infringe privately owned rights. Reference herein to any specific commercial product, process, or service by trade name, trademark, manufacturer, or otherwise does not necessarily constitute or imply its endorsement, recommendation, or favoring by the United States Government or any agency thereof. The views and opinions of authors expressed herein do not necessarily state or reflect those of the United States Government or any agency thereof. 


\section{DISCLAIMER}

Portions of this document may be illegible in electronic image products. Images are produced from the best available original document. 
The facilities of Argonne National Laboratory are owned by the United States Government. Under the terms of a contract (W-31-109-Eng-38) among the U. S. Department of Energy, Argonne Universities Association and The University of Chicago, the University employs the staff and operates the Laboratory in accordance with policies and programs formulated, approved and reviewed by the Association.

\section{MEMBERS OF ARGONNE UNIVERSITIES ASSOCIATION}

The University of Arizona

Carnegie-Mellon University

Case Western Reserve University

The University of Chicago

University of Cincinnati

Illinois Institute of Technology

University of Illinois

Indiana University

The University of Iowa

Iowa State University
The University of Kansas

Kansas State University

Loyola University of Chicago

Marquette University

The University of Michigan

Michigan State University

University of Minnesota

University of Missouri

Northwestern University

University of Notre Dame
The Ohio State University

Ohio University

The Pennsylvania State University

Purdue University

Saint Louis University

Southern Illinois University

The University of Texas at Austin

Washington University

Wayne State University

The University of Wisconsin-Madison

\section{NOTICE}

This report was prepared as an account of work sponsored by an agency of the United States Government. Neither the United States nor any agency thereof, nor any of their employees, makes any warranty, expressed or implied, or assumes any legal liability or responsibility for any third party's use or the results of such use of any information, apparatus, product or process disclosed in this report, or represents that its use by such third party would not infringe privately owned rights. Mention of commercial products, their manufacturers, or their suppliers in this publication does not imply or connote approval or disapproval of the product by Argonne National Laboratory or the United States Government.

Printed in the United States of America

Available from

National Technical Information Service

U. S. Department of Commerce

5285 Port Royal Road

Springfield, VA 22161

NTIS price codes

Printed copy: A03

Microfiche copy: A01 
Distribution Category:

Solar Thermal-Large Scale Systems (UC-62c)

ANL $-79-33$

\section{ARGONNE NATIONAL LABORATORY}

9700 South Cass Avenue

Argonne, Illinois 60439

BIAXIAL CREEP-FATIGUE BEHAVIOR OF TYPE $316 \mathrm{H}$ STAINLESS STEEL TUBE

by

S. Majumdar

Materials Science Division

April 1979

This report was prepared as an account of work This report was prepared as an account of work United Sults un the Unired 5 tates tepartment or Energed stes iny of their employees, nor any of the Energ, hor any of their employees, nor any of their contractors, subcontraciors, of their employees, makes any warranty, express or implied, or assumes any legal

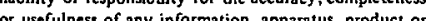
or usefulness of any information, apparatus, product or process disclosed, or represents that its use would not infringe privately owned rights.

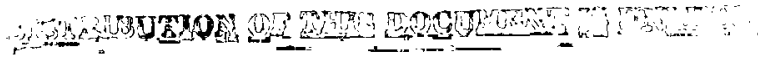


THIS PAGE

\section{WAS INTENTIONALLY \\ LEFT BLANK}


TABLE OF CONTENTS

Page

ABSTRACT . . . . . . . . . . . . . . . . . . 7

I. INTRODUCTION . . . . . . . . . . . . . . . . . . . 8

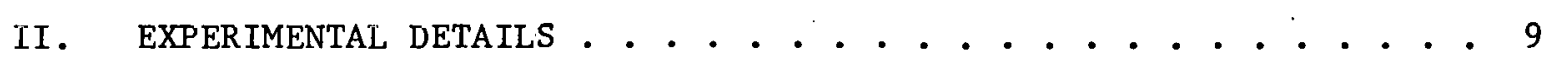

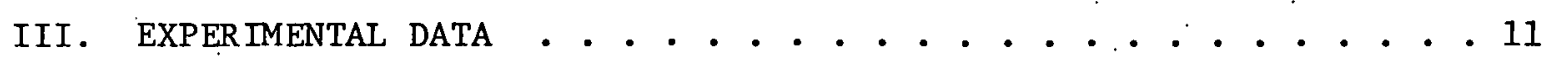

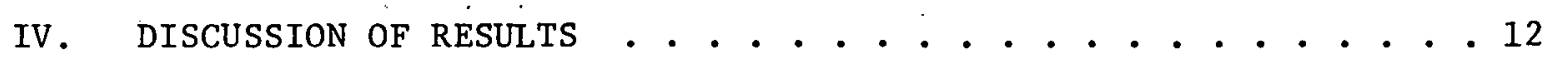

V. CONCLUSIONS AND RECOMMENDATIONS ............... . . 14

ACKNOWLEDGMENTS . . . . . . . . . . . . . . . 15

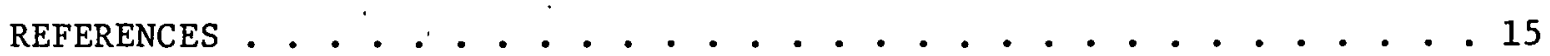




\section{LIST OF FIGURES}

No.

Title

Page

Typical Microstructure of As-received Type 316H Stainless Steel............... 20 Specimen Geometry . . . . . . . . . . . . 20 Typical Test Setup .... . . . . . . . . . . . 21 Close-up View of the Biaxial Fatigue Specimen . . . . . 22 Thermocouple Location . . . . . . . . . . . . 22 Tempcraturc Profilco in a Etraight gauge Specimen . . . 23 Temperature Profiles in an Hourglass Specimen . . . . . 23 Hysteresis Loops for Test No. 997 . . . . . . . . . 24 . Hysteresis Loops for Test No. 999 . . . . . . . . . . 24 Hysteresis Loops for Test No. 1027 . . . . . . . . . . 24 Hysteresis Loops for Test No. 1035 . . . . . . . . . 24 Hysteresis Loops for Test No. 1052 . . . . . . . . . 25 Hysteresis Loops for Test No. 1001 . . . . . . . . 25

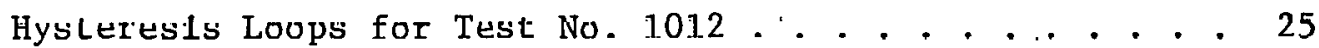
Hysteresis Loops for Test No. 1044 . . . . . . . . . . 25 Hysteresis Loops for Test No. 1024, . . . . . . . . 26 26 Hyeteresis Loope for l'ect No: 1033 . . . . . . . . 26 Hysteresis Loops for Test No. 1049 . . . . . . . . . 26 Hysteresis Loops for Test No. 1038 . . . . . . . . 26 Hysteresis Loops for Test No. 1041 . . . . . . . . 27 Hysteresis Loops for Test No. 1031 . . . . . . . . 27 Hysteresis Loops for Test No. 1059 . . . . . . . . . 27 Hysteresis Loops for Test No. 1050 . . . . . . . . . . 27 Comparison of Axial Hardening Rate for Straight-gauge and Hourglass Specimens... . . . . . . . . . 28 
LIST OF. FIGURES (CONTD.)

No.

Title

Page

25. Comparison of Hysteresis-loop Shapes for Straight-gauge and Hourglass Specimens . . . . . . . . . . . . .

Comparison of Diametral Ratchetting Behavior of Straight-gauge and Hourglass Specimens . . . . . . 28

Stress-relaxation Behavior for Test No. 1033 . . . . . 28

Effect of Internal Pressure on Axial Stress-hardening Rate ..................... 29

Effect of Internal Pressure on the Diametral Ratchetting - 29

Plots of Diametral Ratchetting vs Cycles . . . . . . 29

Plots of Diametral Ratchetting vs Time . . . . . . . 29

Hysteresis Loops for 1-min Tensile and 1-min Compressive Hold-time Tests . . . . . . . . . . . . 30

Scanning Electron Micrograph of the Fractured Surface of Test No. 1044 . . . . . . . . . . . . 30

Scanning Electron Micrograph of the Fractured Surface of Test No. 1033 . . . . . . . . . . . . 30 


\section{LIST OF TABLES}

No.

Title

$\underline{\text { Page }}$

I

Chemistry of Type 316H Stainless Steel Tubing . . . . . . 16

II

Nominal Room-temperature Mechanical Properties of Type

316H Stainless Steel Tubing . . . . . . . . . . . 16

III

Test Matrix . . . . . . . . . . . . . 17

IV

Summary of Biaxial Fatigue Data for Type 316H Stainless Steel ................... 18

V

Summary of Relaxatinn Stresses for the oneminute Holdtime tcats on Type $3 i 6$ stainless 3teèl . . . . . . . . . 19 
BIAXIAL CREEP-FATIGUE BEHAVIOR OF

TYPE $316 \mathrm{H}$ STAINLESS STEEL TUBE

by

S. Majundar

\begin{abstract}
Biaxial creep-fatigue test data for Type 316 stainless steel tubes at $1100^{\circ} \mathrm{F}$ are presented. The specimens were subjected to constant internal pressure and fluctuating axial strain with and without hold times in tension as well as compression. The results show that internal pressure significantly affects diametral ratchetting and axial.stress range. Axial tensile hold is found to be more damaging than axial compressive hold even under a biaxial state of stress.
\end{abstract}

\title{
NOMENCLATURE
}

E. Young's modulus

$\Delta \sigma . \quad$ Axial stress range

$\Delta \varepsilon_{\text {tot }} \quad$ Axial total strain range

$\Delta \varepsilon_{\mathrm{p} 1} \quad$ Axial plastic strain range

$\sigma_{t} \quad$ Axial stress at the beginning of tensile hold time

$\sigma_{c} \quad$ Axial stress at the beginning of compressive hold time

$\sigma_{t} \quad$ Relaxed axial stress at the end of tensile hold time

$\sigma_{t} \quad$ Relaxed axial stress at the end of compressive hold time

$\sigma_{a} \quad$ Axial stress

$\sigma_{\theta} \quad$ Hoop stress

p Internal pressure 


\section{INTRODUCTION}

The highly cyclic nature of solar central receiver operating conditions is likely to create difficult structural design problems. Solar plants will undergo at least one major start-up and shutdown cycle per day, with the likelihood that additional thermal cycles will be imposed by intermittent cloud cover and unscheduled maintenance and repair. Thus, critical elevatedtemperature components may be expected to accumulate on the order of tens of thousands of thermal and associated strain cycles over a 30-year design life. In addition, repeated thermal cycling of superheater or boiler tubing while under internal pressure can lead to incremental growth of the diameter or ratchetting. The analyst must therefore design against structural failure caused by thermal fatigue, rrepp-fatigue interaction and cxccssive deformation caused by ratchetting.

Another aopect of solar-pldul upeidling condiclons likely to cause design difficulties is that, during steady-state operation, the boiler and superheater tubing will be loaded nonaxisymmetrically at elevated temperatures.1,2 In particular, the boiler or the critical passes of the superheater tubing will be loaded during daytime operation such that the outer tubing wall on the high-temperature side will experience a large compressive axial stress and a moderate compressive hoop stress. On the other hand, the inner wall on the high-temperature side will be subjected to a moderate compressive axial stress and a small tensile hoop stress. Considerable information on constitutive relations under compressive and mixed tensile-pluscompressive creep conditions will be required to permit structural analyses of the components. In addition, failure criteria for multiaxial tensileplus-compressive creep-fatigue conditions must be developed.

Elevated-temperature design rules applicable to solar-power-plant boilers and piping are set forth in Section T. of the ASME Boiler and Pressure Vessel Cude. However, Section 1 was not developed with the highly cyclic and of ten complex loading conditions of solar power-p.lant components in mind, and no specific design rules for treating fatigue, creep-fatigue, or ratchetting are provided. Applicable design rules from the nuclear portions of the Code (Section III and Case N47) are likely to result in excessively conservative designs. For example, Case N47 would consider the compressive hold time on the hot side of the superheater tubing to be as damaging as an equal tensile hold time, although available data $\lceil 3\rceil$ indis.ate that this is not the. case for many materials, at least for uniaxial loadings.

Current design procedure for the solar-plant-boiler superheater tubing is to perform a creep-fatigue analysis using elevated-temperature nuclear rules (Case N47) but to ignore creep damage caused by compressive stresses. Thus, hold times under compressive strcsses are assumed to be nundamaging. As stated above, this assumption appears to be reasonable for austenitic stainless steels under uniaxial loading conditions, but it has never been verified for biaxial loading situations, particularly where the stress is tensile in one direction and compressive in the other. Furthermore, virtually no creep-fatigue data exist for Type $316 \mathrm{H}$ stainless steel, which is one of the candidate materials for solar application, even under uniaxial loading conditions. 
Under the present program, biaxial creep-fatigue tests (constant tensile hoop stress and cyclic axial strain with hold times in tension or compression) have been performed on Type $316 \mathrm{H}$ stainless steel superheater tubing material. Times to failure have been shortened by increasing the magnitude of the axial strain range, and by using a considerably shorter hold time, than that expected in service. Details of experiments, results obtained and their discussion are contained in the following sections.

\section{EXPERIMENTAL DETAILS}

\section{A. Material}

Type $316 \mathrm{H}$ stainless steel (Heat No. 180124) used in th1s work was procured from Pacific Tube Co. of Los Angeles, California in the form of 1in.-OD x 0.109-in. min. wall seamless tubing. Chemical analysis of the material, which satisfied ASME specification SA-213, as supplied by the vendor is shown in Table $I$. The nominal room-temperature mechanical properties of the material as supplied by the vendor are shown in Table II. Micrographs of the as-received material, shown in Fig. 1, indicate that the grain structure is generally equiaxed with average grain sizes $32.6 \mu$ (ASTM 6.5). in transverse section and $33.5 \mu$ (ASTM 6.4) in longitudinal section.

\section{B. Specimen Fabrication}

The 1-in.-diameter seamless tubing, which was supplied by the vendor in 17-ft lengths, was cut into 12-in. sections. Some of these were machined to the dimensions shown in Fig. 2a to provide the straight gauge section specimens. The wall thickness at the gauge section was nominally 0.077 in. The wall thicknesses at the center of two of these specimens were reduced by 0.005 and $0.010 \mathrm{in.,}$ respectively, by hand polishing. In the 1atter half of the program, hourglass-shaped specimens were used in order to restrict the failure location to the center of the specimens. These were machined from the remaining 12-in. tube sections as shown in Fig. 2b. A large radius of 9-1/8 in. was used in the hourglassing to minimize stress-concentration. effects $\left(K_{t} \approx 1.01\right)$. The adequacy of this choice was verified by the test results. Each specimen was polished mechanically at the central gauge section to give a finish of better than 8 microinches on both the inner and outer surfaces.

\section{Heat Treatment}

A11 the specimens were tested in the as-received condition without any annealing or preaging treatment.

\section{Test Equipment and Procedure}

The biaxial fatigue testing was carried out in a closed-loop servocontrolled MTS testing machine (Fig. 3) using constant internal pressure and axial strain control. The internal pressure was provided by a commerclally available pressurized nitrogen bottle. The axial strain in the 
specimens was measured by a high-temperature axial extensometer with a 1/2in. gauge length, and the diametral strain was measured by a high-temperature diametral extensometer. The axial load was measured by a 40-kip load cell placed in series with the specimen. The specimen was heated by a Lepel induction heater operating at a frequency of $455 \mathrm{kHz}$. Figure 4 shows a close-up view of a specimen inside the induction heating coil with the axial and diametral extensometers in position.

In order to determine the temperature distribution in the test specimens a total of 44 thermocouples ( 11 along each of four azimuthal planes) were distributed axially along the specimen at 1/4-in. intervals (Fig. 5). Figure 6 shows typical temperature profiles in a straight-gauge specimen at 0,1100 and 2000 psi internal pressure. Figure 7 shows similar plots for the hourglass specimen. Note that the temperature profiles are dependent upon the internal pressure and the specimen geometry. However, for a given specimen geometry at a fixed internal pressure the tempcraturc profile was reproducible to within $+5^{\circ} \mathrm{F}$. The dip in the center of the temperature profile is caused by the heat carried away by the extensometers, which act as heat sinks. The maximum temperature variation over the central $1 / 2$ in. of the gauge section was about $20^{\circ} \mathrm{F}$ for both the hourglass and straight-gauge specimens. In an actual test the temperature in the specimen was regulated by a control thermocouple spot welded at a distance of $1-1 / 4$ in. from the center for the straight-gauge specimen and 1 in. for the hourglass specimen. Eight other thermocouples were attached to the specimen, four at the top and four at the bottom, distributed symetrically about the center and at the same distance from it as the control thermocouple. The set point in the Lepel heater was then adjusted so that the average reading of these thermocouples corresponded to the desired temperature in the central $1 / 2 \mathrm{in}$. of the specimen as determined from the calibrated specimen. A1though the specimen wall is thinnest in the central region, several specimens failed outside this region, at one of the thermocouple locations.

Since the specimen grip was of the split-collar clamping-ring typc, special care was taken in aligning the specimen while the clamping-ring bolts were tightened. Four strain gauges were attached at $90^{\circ}$ intervals around the circumference near the bottom end of the specimen. The bottom end of the spectmen was first gripped and the rlamping-ring bolts were tightened sequentially while maintaining alignment at the ton end by a mechanical gaugc. The readings on the strain gauges were noted, and the top end of the specimen was then gripped and the clamping-ring bolts tightened sequentially to minimize bending. The specimen was then axially loaded in both tension and compression in the elastic range to ensure that no bending occurred as indicated by the strain gauges. Good alignment of the specimen was further evidenced by initiation of multiple cracks around the circumferences of many fractured specimens.

The test procedure consisted of first heating the specimen to the desired temperature with zero axial load, and holding the temperature steady until the whole system came to thermal equilibrium. The internal pressure, if any, was then applied and the specimen was kept at the temperature for sufficient time to allow the new temperature distribution to come to equilibrium. The specimen was then cycled axially under axial strain control. 
Hysteresis loops of axial stress versus axial strain and axial strain versus diametral strain were recorded on $x-y$ plotters at regular intervals. Each Individual signal was also plotted on a strip-chart recorder. For the internally pressurized specimens, the test was shut down automatically when a crack penetrated through the wall. For the unpressurized specimens, the test was shut down automatically when the specimen fractured. The number of cycles to failure was determined from the diametral-strain strip-chart recording at the onset of rapid change in the diametral strain. No attempt was made to measure crack lengths in the specimens. Some of the fracture surfaces of the specimens were studied using scanning electron microscopy.

\section{E. Test Matrix}

A11 testing was carried out at a total strain range of $0.5 \%$ and at a nominal temperature of $1100^{\circ} \mathrm{F}$. Tests were carried out with 0,1100 , and 2000 psi constant internal pressure and with 0 , 1-minute tensile and 1-minute compressive hold times (at the maximum axial strain limit). A total of 16 tests were conducted. The first 10 were on straight-gauge specimens. Since some of these specimens failed outside the axial extensometer gauge length, the latter 6 tests were conducted with the hourglass specimens; this alleviated the problem. A description of the test matrix is given in. Table III.

\section{EXPERIMENTAL DATA}

A summary of all the biaxial fatigue tests conducted on Type 316 stainless steel tubes is shown in Table IV where the reported plastic strain range, diametral strain range and axial stress range are measured at approximately the half life of each test. The temperatures reported in the third column are the calculated average temperatures at the gauge section. The axial plastic strain ranges $\left(\Delta \varepsilon_{\mathrm{pl}}\right)$ reported were computed from the measured axial total strain ranges $\left(\Delta \varepsilon_{\text {tot }}\right)$ and the axial stress ranges $(\Delta \sigma)$ by the equation

$$
\Delta \varepsilon_{\mathrm{p} 1}=\Delta \varepsilon_{\text {IOt }}-\frac{\Delta \sigma}{E}
$$

where

$$
E=22.2 \times 10^{6} \mathrm{psi}
$$

The hoop-stress values reported were computed by the thin-wall tube-approximation formula using the average radius of the tube. The diametral strains reported are the calculated hoop strains at the outside-diameter surface, obtained by dividing the measured diametral displacements by the outside diameter of the tube at the gauge section.

Traces of the axial stress-axial strain hysteresis loops at cycles 1 , 10, and the approximate half life for all the tests are given in Figs. 8 to 
23. The axial stresses on these plots have not been corrected for the component due to internal pressure. The corrections are about +2.5 and +4.6 ksi for the 1100- and 2000-psi internal-pressure cases, respectively. However, the axial stresses reported in Table IV include the corrections due to internal pressure.

The stress-relaxation data for all the hold-time tests are included in Table V: $\sigma_{t_{0}}$ and $\sigma_{c_{0}}$ represent stresses at the beginning of the tensile and compressive hold time, respectively, and $\sigma_{t_{R}}$ and $\sigma_{c_{R}}$ represent the relaxed stresses at the end of the tensile and compressive hold time, respectively.

\section{DISGUESEION OF RESULTS}

An examination of l'able IV shows that the stress-strain data for the hourglass and straight-gauge specimens are similar; the same is true of the failure data. However, the likelihood of the specimen failing outside the axial extensometer tips is much sma11er for the hourglass sperimens than for the straight-gauge specimens. The axial stress hardening with cycles for three continuous-cycling tests is shown in Fig. 24. Note that the straightgauge and hourglass specimens show similar hardening behavior. The slightly smaller stress range for the hourglass specimens could be the result of the fact that they were tested at an $240-50^{\circ} \mathrm{F}$ higher temperature than the straight-gauge specimens. A comparison of the hysteresis loops at half life for the two types of specimens subjected to 1-min tensile-hold loading is shown in Fig. 25. Although the straight-gauge sperimens shnal slightly larger stress ranges than the hourglass specimens, they are considered to be within the same scatter band. A comparison of the ratchetting behavior of the hourglass and straight-gauge specimens is shown in Fig. 26. Note that the two types of specimens behave similarly even though the tensile-hold specimens ratchet more than the compressive-hold specimens in the early part of the tests. In all cases, however, the hourgl.ass specimens tend to ratchet more than the straight-gauge specimens for the first few cycles. This could be the results of the slight stress concentration that occurs in the hourglass spiecimens.

The stress-relaxation behavior is similar for the two types of specimens (Table V). However, the hourglass specimens consistently tend to have a slightly lower stress than the straight-gauge specimens. The amount of axial stress relaxation seems to be independent of specimen type and internal pressure. Typical stress-relaxation behavior for a one-minute compressivehold test is shown in Fig. 27. Note that in spite of considerable hardening as the number of cycles increases, the amount of stress relaxation per cycle is approximately constant. The rapid drop in the stress at the beginning of the hold time occurs for two reasons. First, the load drop is a result of the anelastic effect caused by the sudden change in the applied strain rate. Secondly, because of the inertia of the test system, strain in the specimen slightly exceeds the strain limits before going into the hold-time mode. 
The rapid load drop is thus partially a result of the attempt by the closedloop system to correct for the slight overshoot in strain.

The effect of internal pressure on the axial stress hardening is shown in Fig. 28. The specimens with higher internal pressure tend to have a higher rate of hardening as well as a larger half-life stress range. This may be due to the larger diametral ratchetting experienced by the specimen with larger internal pressure. Tests without diametral ratchetting (i.e., with both internal and external pressure) are necessary to determine whether this hardening is truly a biaxial stress effect or whether it is a consequence of the mean plastic strain that accumulates as a result of ratchetting. Another interesting feature of Fig. 28 is that the specimens without hold time reach a stable stress range with cycling whereas the specimens with either tensile or compressive hold time continue to harden to the end of the test without ever really attaining a stable stress-range value.

The effect of internal pressure on the ratchetting behavior of the tubes under continuous cycling is shown in Fig. 29. As expected, the higher the internal pressure, the larger the diametral ratchetting. Note that although tests 1001,1012 and 1044 were each tested with an internal pressure of 1100 psi, test 1044 had about 50\% more ratchetting than the other two. The reason for this can be traced to the temperature of specimen 1044, which was about $50^{\circ} \mathrm{F}$ hotter than the other two (see Table IV). Similarly, test 1031 showed more ratchetting than test 1059 under an internal pressure of 2000 psi because the latter specimen was about $30^{\circ} \mathrm{F}$ cooler than the former. This strong dependence of ratchetting on temperature suggests that the majority of the ratchetting strain is due to thermally activated creep. It is interesting to note that if one analyzed these specimens on the assumption that creep is negligible because no hold time is involved in the cycle, one would grossly underestimate the diametral ratchetting strain. In fact, a rate-independent plasticity analysis of the tube would show a saturation in ratchetting strain after accumulation of a much smaller amount of diametral plastic strain than is observed in the tests. ${ }^{4}$ Th1s points out the importance of including creep effects during transient loadings in a ratchetting analysis. However, it is expected that as the hold time increases, the contrihutinn of thermal creep to the ratchetting will become more significant during hold times than during the transients. It is interesting to plot the diametral ratchetting as a function of the number of cycles as well as with time for tests with and without hold times. Such plots are shown in Figs. 30 and 31 . Note that the specimens subjected to continuous cycling ratchet faster than the ones subjected to hold time when the data are plotted against time. However, the reverse might be true when the data are plotted against cycles.

Another interesting observation can be made regarding the hysteresis loop shape for the tests with hold times. Although the tension going and the compression going halves of the hysteresis loop were similar in shape for the first $f e w$ hundred cycles, this is not the case when the specimen has hardened significantly. Representative hysteresis loops are shown for the 1-min tensile-hold and 1-min compressive-hold tests in Fig. 32 . Note that the tension going half of the hysteresis loop of the tensile-hold test and 
the compression going half of the hysteresis loop of the compressive-hold test are almost bilinear in shape, whereas the remaining halves of the hysteresis loops are rounded as usual. Such behavior was not observed for the continuous-cycling tests. The reason for this is not fully understood but is suspected to be related to the asymmetry in the dislocation structure created by the unsymmetric hold time.

The fracture surfaces of some of the specimens were examined by scanning electron microscopy. A number of failed specimens displayed evidence of multiple crack. initiation around the circumference of the tube, Indicating that specimen alignment was adequate. It was found that under continuous cycling and with 1-min compressive hold time with or without internal pressure, the specimens failed transgranularly with striations appearing on the fracture surface (FIgs. 33 and 34). However, for the 1min tensile-hold test the frarture was predominantly intergrainulai

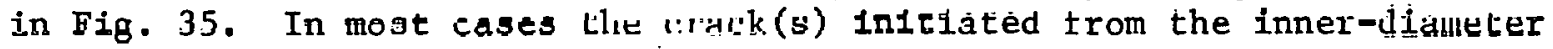
surface and propagazed outwards.

\section{CONCLUSIONS AND RECOMMENDATIONS}

The hourglass type of specimen is preferable to the straight-gauge type for conducting biaxial fatigue testing. The two types of specimens are similar with respect to both stress-strain response and ratchetting behavior.

Type $316 \mathrm{H}$ stainless steel (as received) hardens cyclically; both the rate of hardening and the stable axial stress range increase with increasing internal pressure. It is not clear whether this difference in hardening behavior is due to the biaxiality of the stress field or to the larger diametral ratchetting in the specimens associated with larger internal pressure. Tests with both internal and external pressures (to prevent ratchetting) are needed to determine whether this behavior is truly due to the biaxiality nf Llie stress fleld or not.

The effect of internal pressure (up to $2000 \mathrm{psi}$ ) on the continuouscycling and 1 -min compressive-hold fatigue 1 ife at $1100^{\circ} \mathrm{F}$ is small. However, it must be remembered that the biaxiality of the stress field $\left(\sigma_{\theta} / \sigma_{a}\right)$ in these tests was small. Future testing should concentrate on lower axial strain ranges so that the biaxiality of the stress field is more significant.

The 1-min axial tensile hold is more damaging than the 1-inin axial compressive hold for this material at $1100^{\circ} \mathrm{F}$ even under a biaxial state of stress. This is also borne out by microstructural observation of the fracture surface. The compressive-hold tests fail transgranularly, whereas the tensile-hold tests fail intergranularly.

Although tensile hold is more damaging than compressive hold for this material, the damage during compressive hold is not zero. Tests with longer hold time in compression together with larger biaxiality in the stress field are needed to simulate more closely the type of loading expected in a central solar receiver tube. 
ACKNOWL EDGMENTS

The author would like to thank Michael Gorman for conducting the tests and reducing much of the test data and Don Busch for his help in the SEM work. Thanks are also due to Bill Burke for his constant help in running the tests. The author would also like to express his gratitude to Bill Moore of Sandia Laboratories, Livermore, for his support and encouragement.

\section{REFERENCES}

1. Central Receiver Solar Thermal Power System, Phase 1, Pilot Plant PreIiminary Design Report, Vol. IV, Receiver Subsystem, McDonnell Douglas Astronautics Company Report MDC G6776, May 1977.

2. Central Receiver Solar Thermal Power System, Phase 1, Progress Report for Period Ending December 31, 1975, prepared by Martin Marietta Corporation for the Energy Research and Development Administration, Division of Solar Energy, SAN/1110-76/T1, April 1976.

3. J. B. Conway, R. H. Stentz and J. T. Berling; Fatigue, Tensile and Relaxation Behavior of Stainless Steels, USAEC, TID-26135, 1975.

4. Gopal Gupta, Foster Wheeler Development Corporation, Livingston, New Jersey, personal communication (1978). 
Table I. Chemistry of Type $316 \mathrm{H}$ Stainless Steel Tubing (Heat 180124)

\begin{tabular}{lcc}
\hline & \multicolumn{2}{c}{ Content, wt. \% } \\
\cline { 2 - 3 } Element & Ladle Analysis & Check Analysis \\
\hline C & 0.05 & 0,06 \\
Mn & 1.62 & 1.64 \\
P & 0.024 & 0.022 \\
S & 0.012 & 0.012 \\
Si & 0.60 & 0.60 \\
Ni & 11.96 & 11.87 \\
Cr & 17.00 & 16.91 \\
Mo & 2.26 & 2.22 \\
\hline
\end{tabular}

Table II. Nominal Room-temperature Mechanical Properties uf Type 316H Stainless Steel Tubing (Heat 180124)

\begin{tabular}{lcccc}
\hline $\begin{array}{c}\text { U1t1mate } \\
\begin{array}{c}\text { Strength, } \\
\text { ksi }\end{array}\end{array}$ & $\begin{array}{c}\text { Yield } \\
\text { Strength, } \\
\text { ksi }\end{array}$ & Elvingation & $\begin{array}{c}\text { Rockwell } \\
\text { Hardness }\end{array}$ & $\begin{array}{c}\text { Grain } \\
\text { Size }\end{array}$ \\
\hline 85.25 & 46.39 & 65 & $76=80$ & $\begin{array}{c}\text { As'lM } \\
\text { \#6 }\end{array}$ \\
\hline
\end{tabular}


Table III. Test Matrix ${ }^{a}$

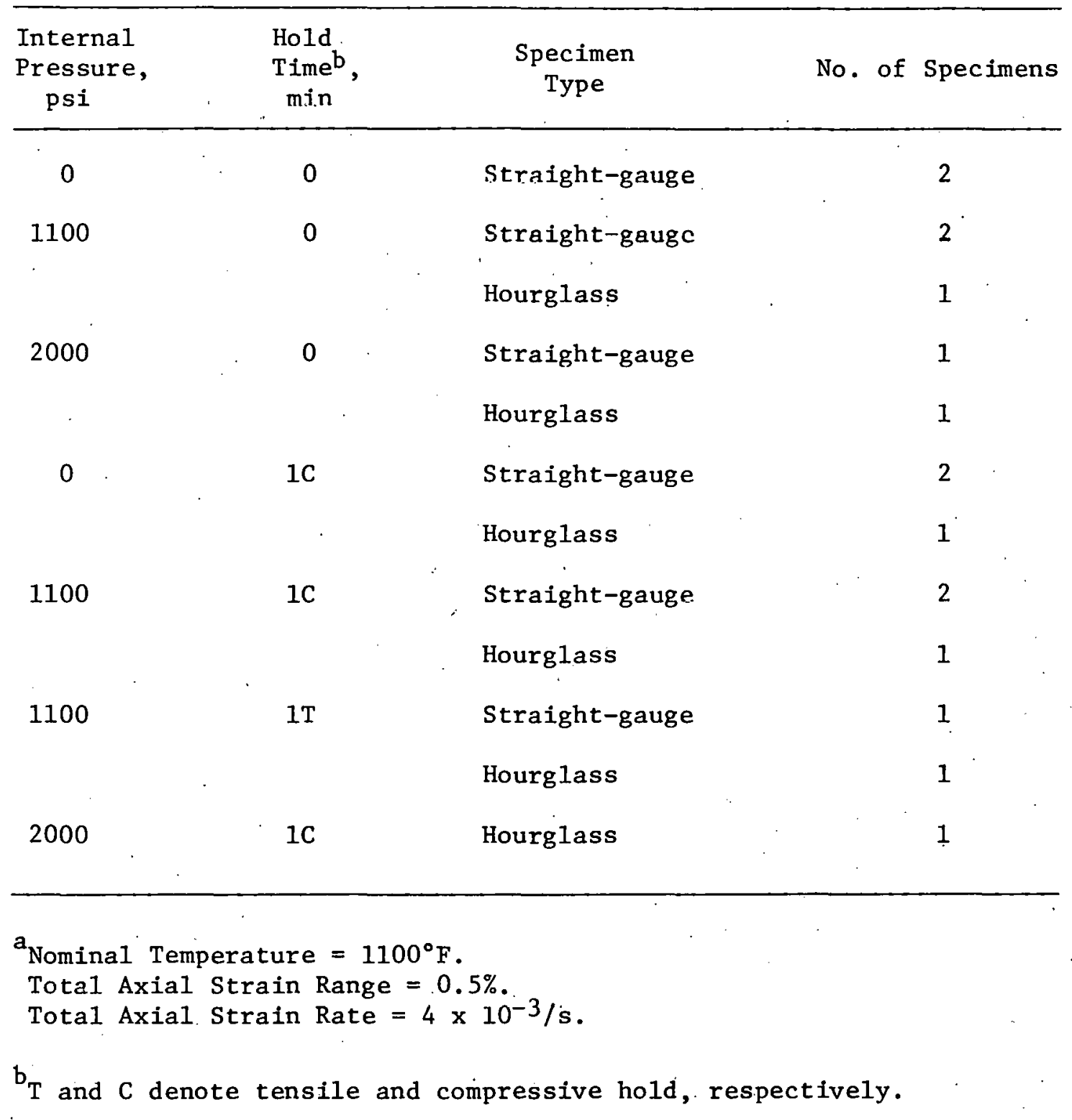


Table IV. Surmary of Biaxial Fatigue Data for Type 316H Stainless Steel

\begin{tabular}{|c|c|c|c|c|c|c|c|c|c|c|c|c|}
\hline $\begin{array}{l}\text { Test } \\
\text { No. }\end{array}$ & $\begin{array}{l}\text { Specimen } \\
\text { Type }\end{array}$ & $\begin{array}{l}\text { Tenp. } \\
{ }^{\circ} \mathrm{F}\end{array}$ & $\begin{array}{l}\text { Hold } \\
\text { Time } \\
\text { min }\end{array}$ & $\begin{array}{l}\text { Znternal } \\
\text { Pressure, } \\
\text { psi }\end{array}$ & \multicolumn{2}{|c|}{$\begin{array}{c}\text { Axial Strain } \\
\text { Range, } \%\end{array}$} & $\begin{array}{c}\text { Diametral } \\
\text { Strain } \\
\text { Range, } \\
\%\end{array}$ & \multicolumn{2}{|c|}{$\begin{array}{c}\text { Axial } \\
\text { Stres:3, } \\
\text { ksi }\end{array}$} & $\begin{array}{l}\text { Average } \\
\text { Hoop } \\
\text { Stress, } \\
\text { ksi }\end{array}$ & $\begin{array}{l}\text { Cycles to } \\
\text { Failure }\end{array}$ & $\begin{array}{c}\text { - Mean } \\
\text { Diametral } \\
\text { Strain at } \\
\text { Failure, } \\
\%\end{array}$ \\
\hline 997 & Str. gauge & 1065 & 0 & 0 & 0.51 & 0.19 & 0.20 & 71.5 & \pm 0.1 & 0 & 14156 & -0.02 \\
\hline 1035 & Str. gauge $e^{c}$ & 1100 & $1 \mathrm{C}$ & 0 & 0.49 & 0.15 & 0.21 & 75.1 & $\div 1.1$ & 0 & $9750^{d}$ & -0.06 \\
\hline 1052 & Hourglass & 1100 & $1 \mathrm{C}$ & 0 & 0.50 & 0.17 & 0.19 & 74.0 & $\div 1.7$ & 0 & 13518 & -0.10 \\
\hline 1001 & Str. gauge & 1054 & 0 & 1100 & 0.50 & 0.17 & 0.19 & 74.3 & $\div 0.7$ & 6.1 & 15566 & +1.05 \\
\hline 1012 & Str. gauge & 1070 & 0 & 1100 & 0.50 & 0.17 & 0.20 & 72.3 & $\div 0.8$ & 6.1 & 9229 & +0.96 \\
\hline 1049 & Hourglass & $11(i i)$ & $1 \mathrm{C}$ & 1100 & 0.50 & 0.16 & 0.20 & 75.9 & +1.9 & 6.1 & 8283 & +1.98 \\
\hline 1038 & Str. gauge $\mathrm{f}^{\mathrm{f}}$ & 1100 & $1 \mathrm{~T}$ & 1100 & 0.50 & 0.15 & 0.17 & 7.6 .8 & +0.1 & 6.1 & 3821 & +1.21 \\
\hline 1041 & Hourglass & 1125 & $1 \mathrm{~T}$ & 1100 & 0.50 & 0.16 & 0.18 & 74.8 & +0.2 & 6.1 & 2746 & +1.04 \\
\hline 1031 & Str. gauge & 1123 & 0 & 2000 & 0.50 & 0.15 & 0.17 & 77.6 & +0.2 & 11.0 & $6739^{d}$ & +2.5 \\
\hline 1059 & Hourglass & $11(0)$ & 0 & 2000 & 0.50 & 0.15 & 0.19 & 77.4 & -0.1 & 11.0 & $14583^{e}$ & +3.15 \\
\hline 1050 & Hourglass & $11(10)$ & $1 \mathrm{C}$ & 2000 & 0.50 & 0.12 & 0.20 & 84.2 & +1.6 & 11.0 & $7140^{d}$ & +4.67 \\
\hline
\end{tabular}

${ }^{a_{T}}$ and $C$ denote tensile and compressive hold, respectively.

${ }^{b}$ Specimen overstrained due to power interruption.

${ }^{c}$ Specimen wall thickness reduced by 0.005 in: at certer by polishing.
${ }^{a}$ Specimen failed outside gauge section.

especimen failed at thermocouple.

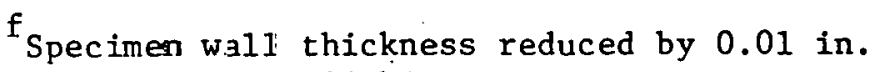
at center jy polishing. 
Table V. Summary of Relaxation Stresses for the One-minute Hold-time tests on Type 316 Stainless Steel

\begin{tabular}{|c|c|c|c|c|c|c|c|c|}
\hline \multirow{2}{*}{$\begin{array}{l}\text { Test } \\
\text { No. }\end{array}$} & \multirow{2}{*}{ Specimen Type } & \multirow{2}{*}{$\underset{{ }^{\circ} \mathrm{F}}{\text { Temp. }}$} & \multirow{2}{*}{$\begin{array}{l}\text { Hold } \\
\text { Time, } \\
\text { min }\end{array}$} & \multirow{2}{*}{$\begin{array}{l}\text { Internal } \\
\text { Pressure, } \\
\text { psi }\end{array}$} & \multicolumn{2}{|c|}{$\begin{array}{c}\text { Tensile Stress, } \\
\text { ksi }\end{array}$} & \multicolumn{2}{|c|}{$\begin{array}{l}\text { Compressive } \\
\text { Stress, ksi }\end{array}$} \\
\hline & & & & & $\sigma_{t}$ & $\sigma_{t}$ & $\sigma_{c}$ & $\sigma_{c}$ \\
\hline 1027 & Straight-gauge & 1144 & $1 \mathrm{C}$ & 0 & 38.0 & - & 36.8 & 34.7 \\
\hline 1035 & Straight-gauge & 1100 & $1 \mathrm{C}$ & 0 & 38.7 & - & 36.4 & 34.6 \\
\hline 1052 & Hourglass & 1100 & $1 \mathrm{C}$ & 0 & 38.7 & - & 35.3 & 32.7 \\
\hline 1024 & Straight-gauge & 1132 & $1 \mathrm{C}$ & 1100 & 40.3 & - & 37.9 & 35.7 \\
\hline 1033 & Straight-gauge & 1123 & $1 \mathrm{C}$ & 1100 & 40.9 & - & 37.9 & 35.2 \\
\hline 1049 & Hourglass & 1100 & $1 \mathrm{C}$ & 1100 & 39.9 & - & 36.0 & 33.6 \\
\hline 1050 & Hourglass & 1100 & $1 \mathrm{C}$ & 2000 & 43.7 & - & 40.5 & 37.8 \\
\hline 1038 & Straight-gauge & 1100 & $1 \mathrm{~T}$ & 1100 & 38.5 & 35.9 & 38.3 & - \\
\hline 1041 & Hourglass & 1125 & $1 \mathrm{~T}$ & 1100 & 37.6 & 35.1 & 37.2 & - \\
\hline
\end{tabular}




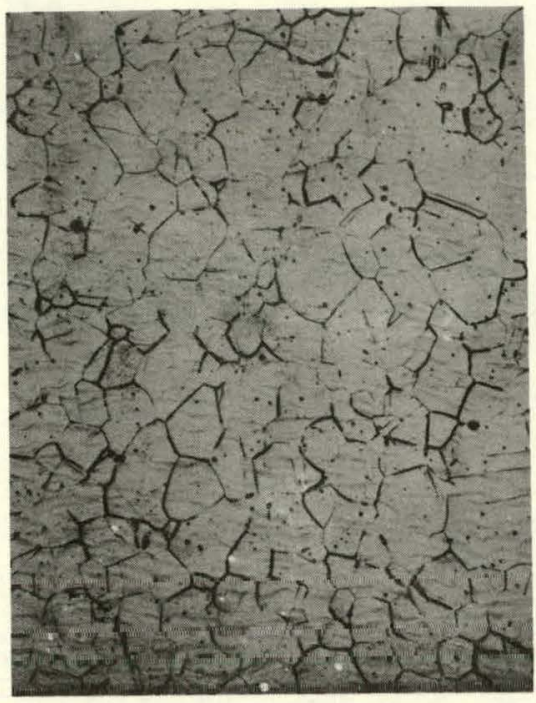

Transverse Section

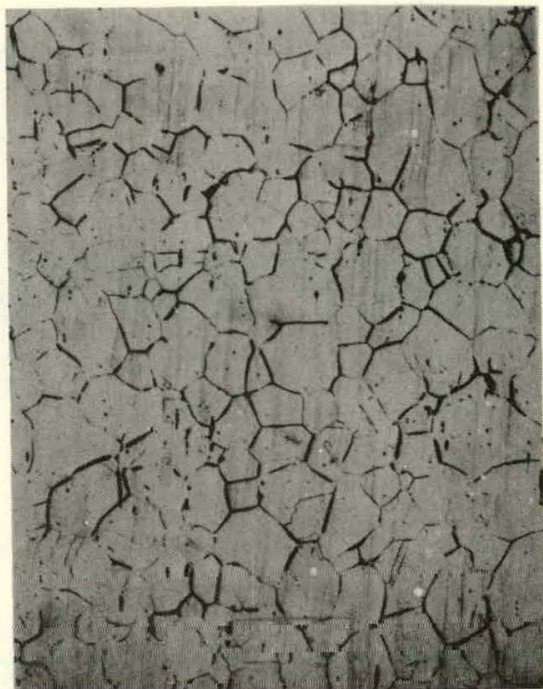

Longltudinal Sectlon

$100 \mu$

Fig. 1. Typical Microstructure of As-received Type $316 \mathrm{H}$ Stainless Stee1. Neg. No. MSD-66265.

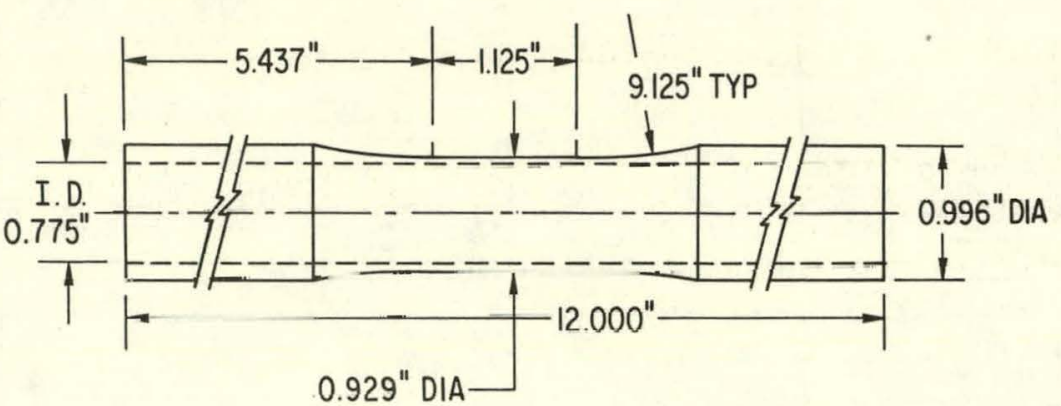

(a)

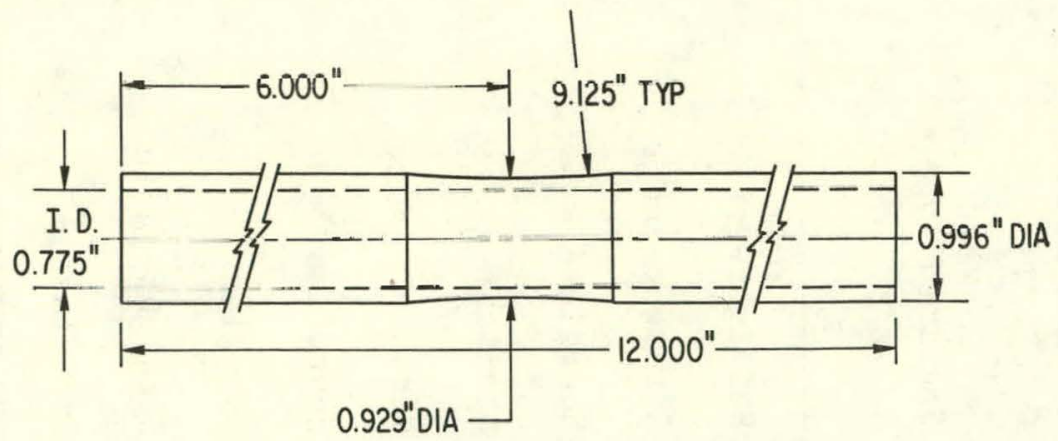

(b)

Fig. 2. Specimen Geometry. (a) Straight gauge;

(b) hourglass. Neg. No. MSD-66258. 


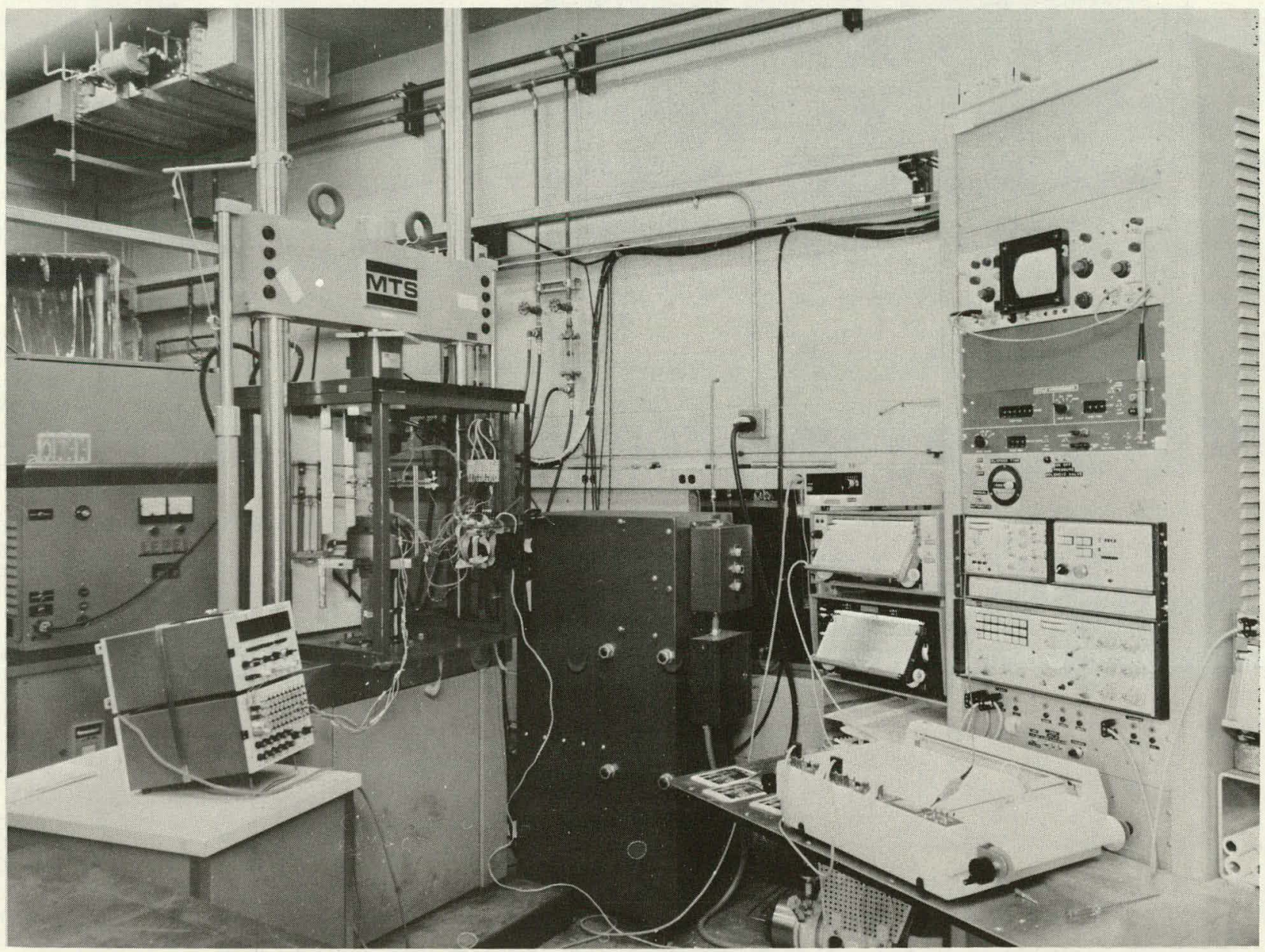

Fig. 3. Typical Test Setup. 


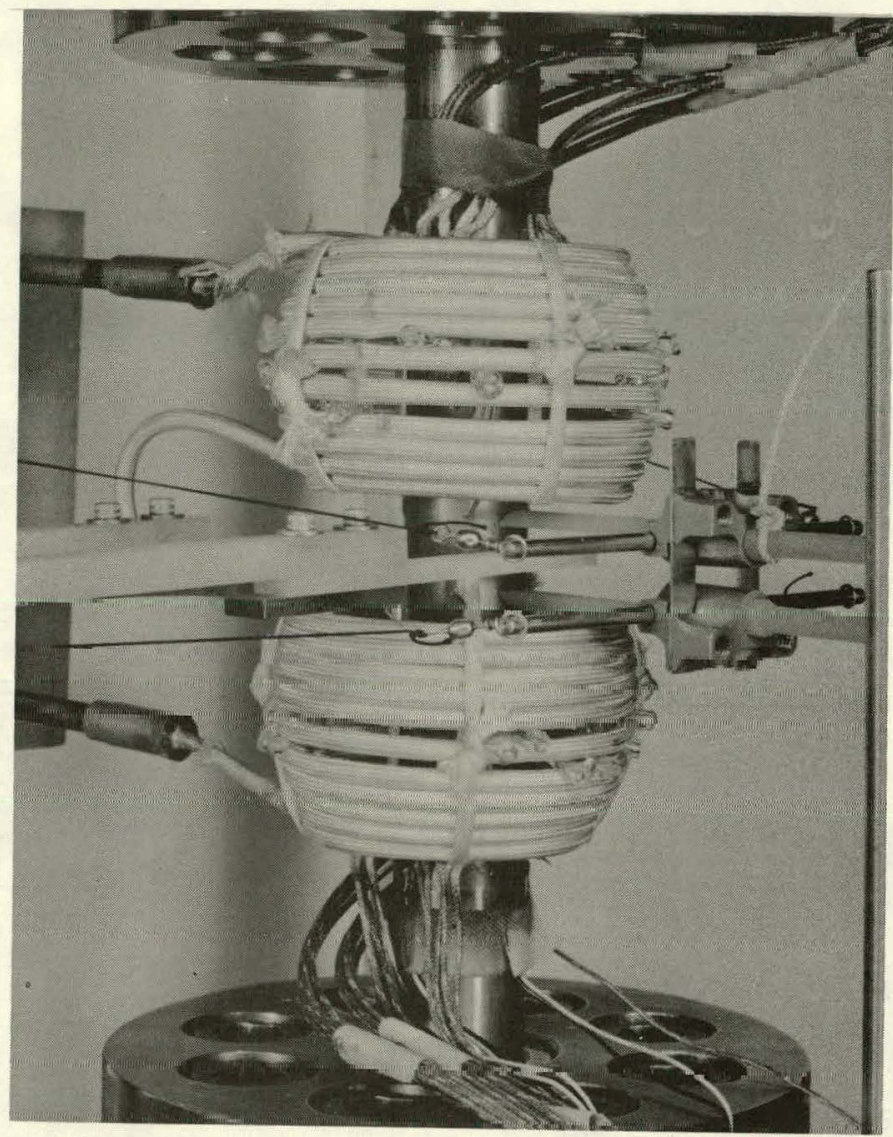

Fig. 4

Close-up View of the Biaxial Fatigue Specimen.

Fig. 5

Thermocouple Location. ANL Neg. No. 306-79-118.

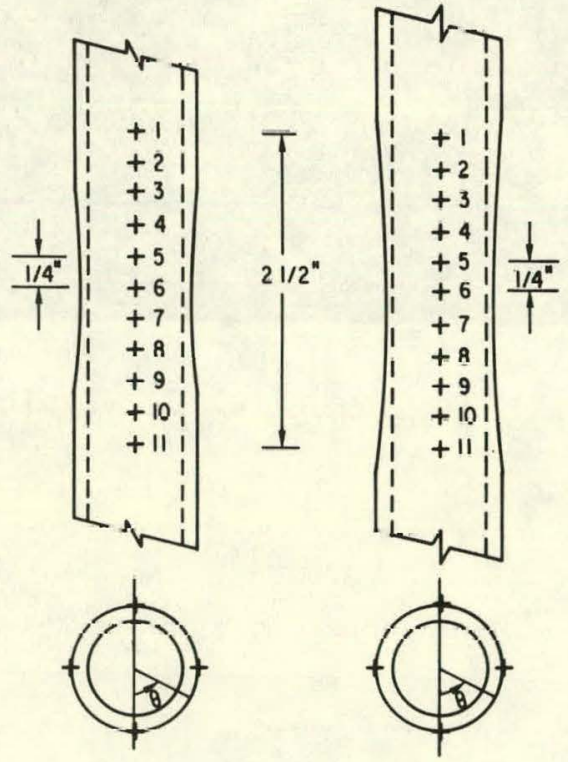




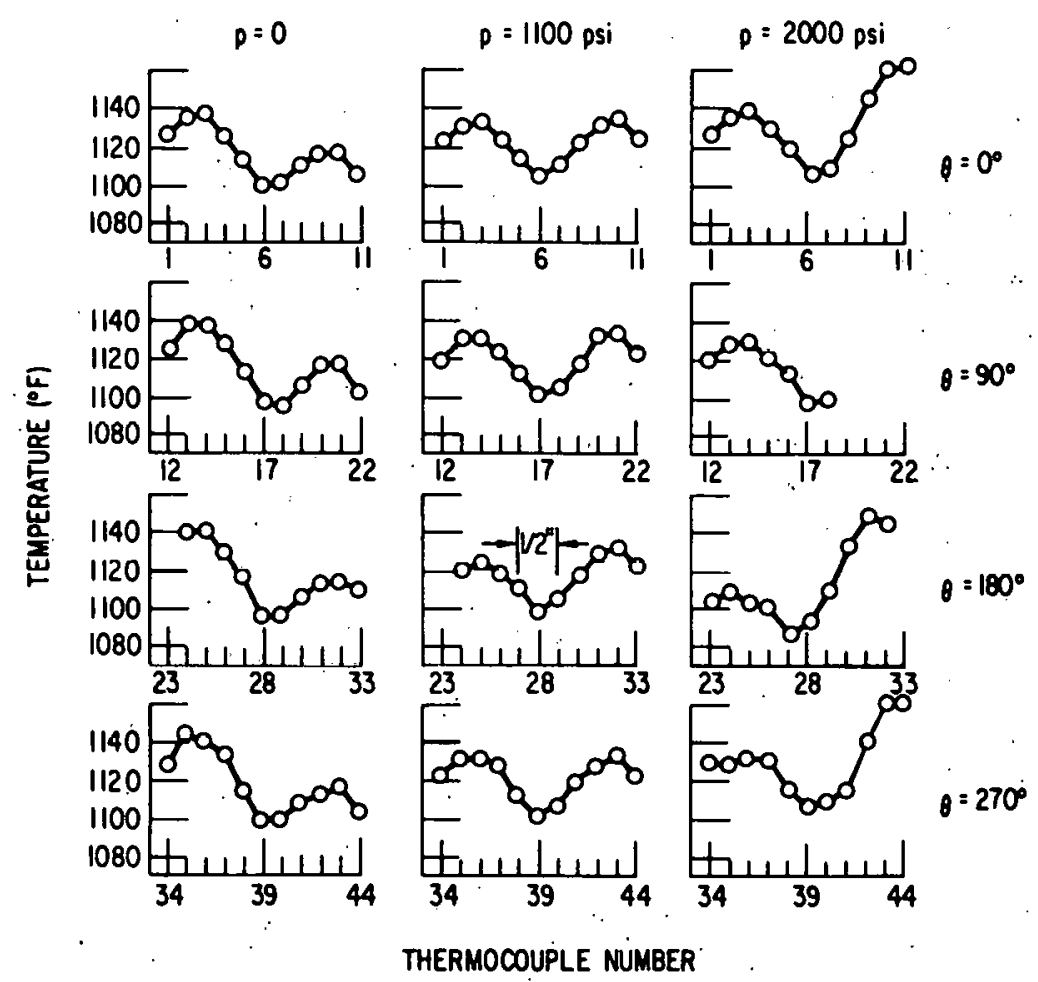

Fig. 6. Temperature Profiles in a Straight-gauge Specimen. ANL Neg. No. 306-79-120.

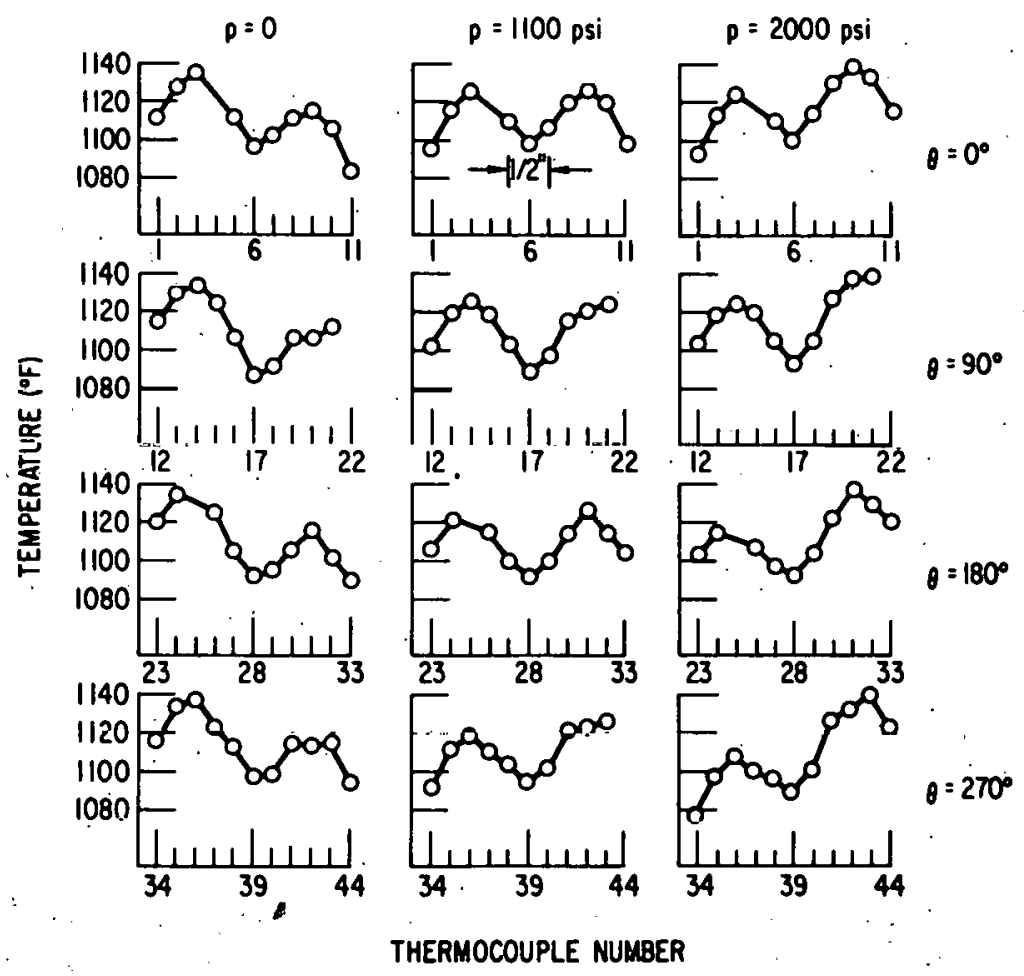

Fig. 7. Temperature Profiles in an Hourglass Specimen. ANL Neg. No. 306-79-116. 


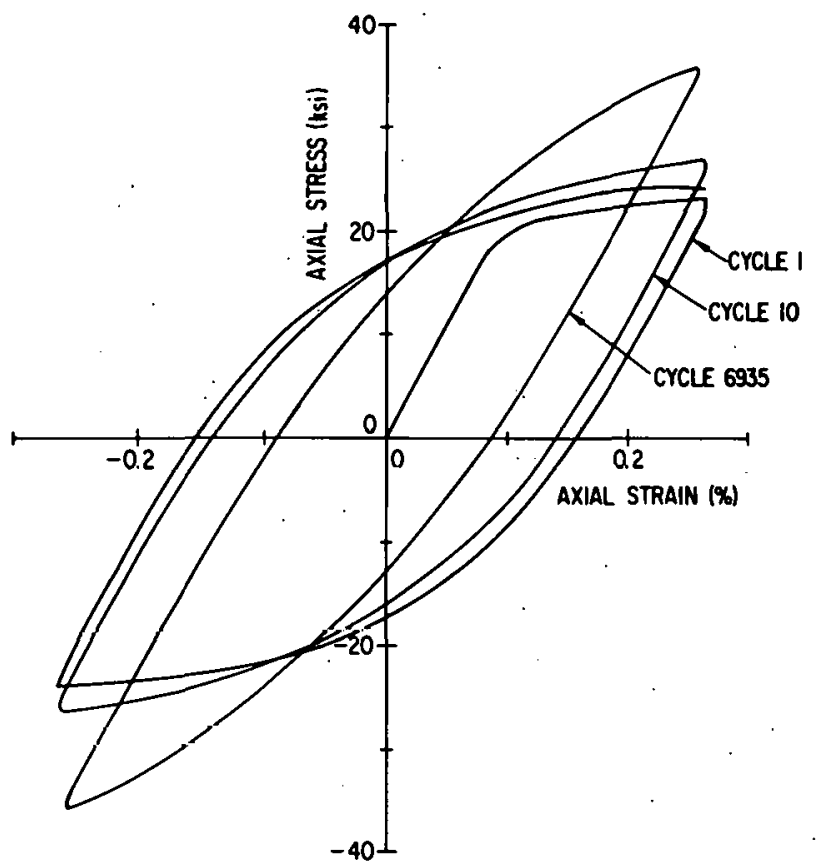

Fig. 8. Hysterisis Loops for Test No. 997. ( $(\mathrm{p}=0$, hold time $=0$. ) Neg. No. MSD-66261.

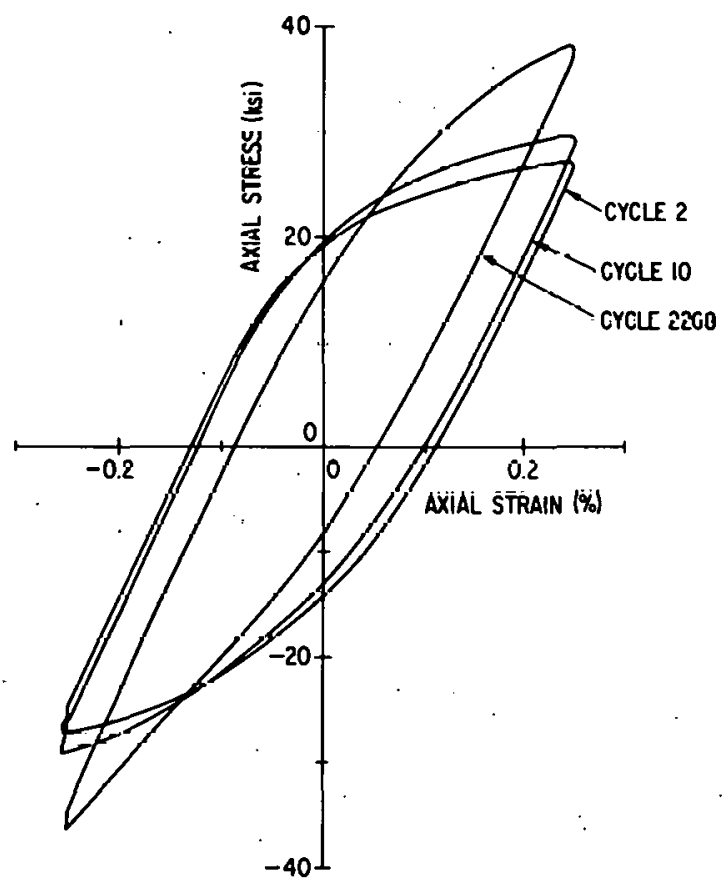

$\mathrm{XX}_{\mathrm{X}}$ Fig. 10. Hysterisis Loops for Test No. 1027. ( $p=0$, hold time = 1C.) Neg: No. MSD-66247.

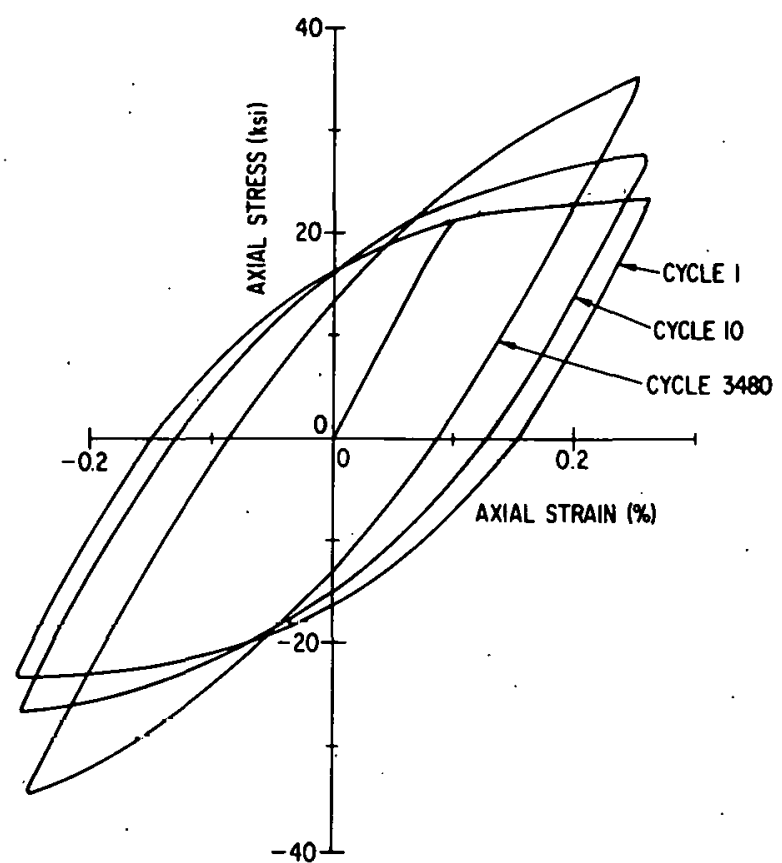

Fig. 9. Hysterisis Loops for Test No. 999. ( $p=0$, hold time $=0$.$) Neg. No.$ MSD-66241.

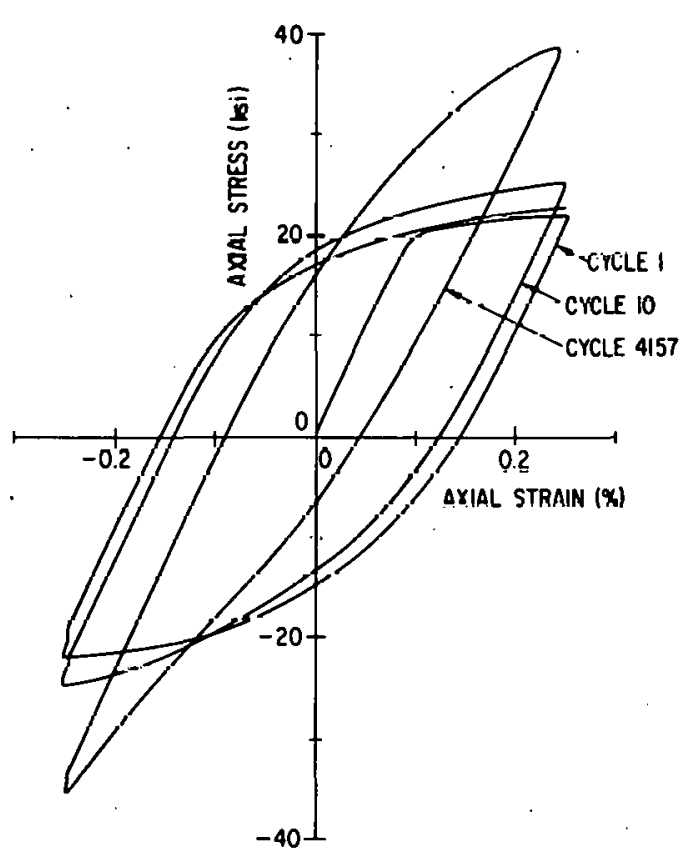

Fig. 11. Hysterisis Loops for Test No. 1035. ( $p=0$, hold time = 1C.) Neg. No. MSD-66248. 


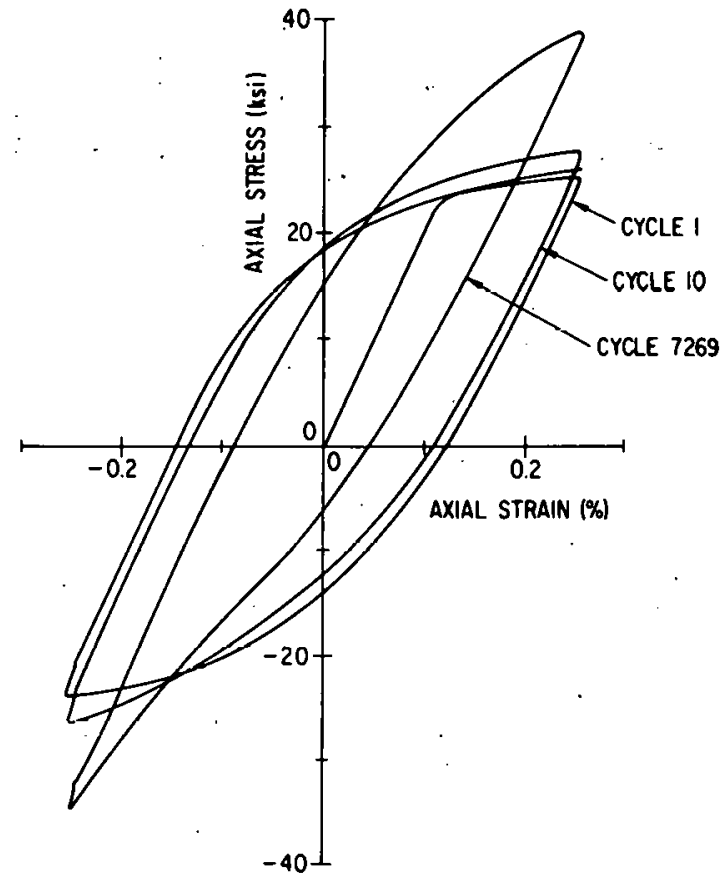

Fig. 12. Hysteresis Loops for Test No. 1052. ( $p=0$, hold time = 1C.) Neg. No. MSD-66252.

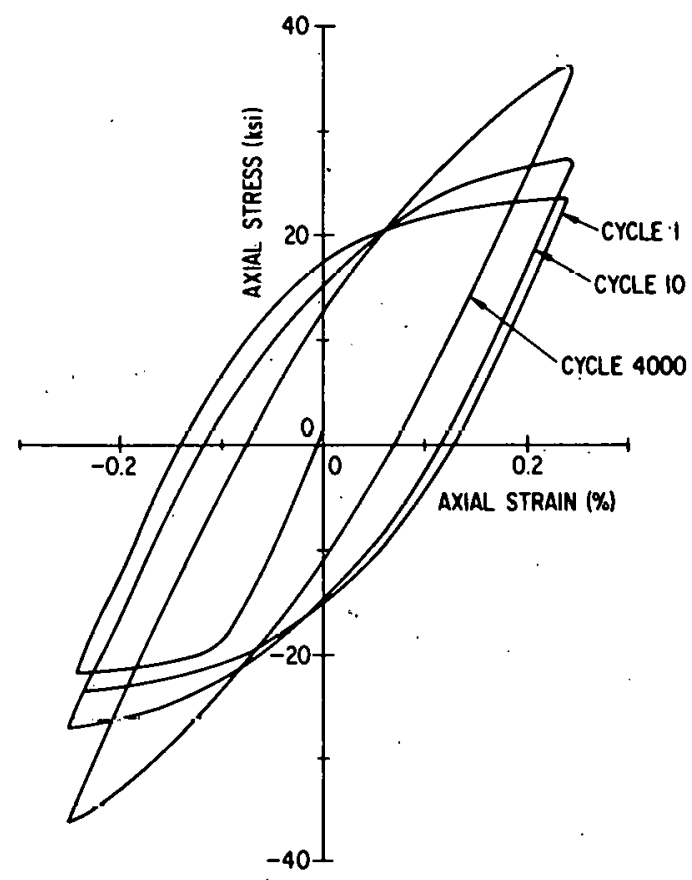

$\mathrm{X}$

Fig. 14. Hysteresis Loops for Test No. 1012. ( $p=1100$ psi, hold time $=0$. ) Neg. No. MSD-66238.

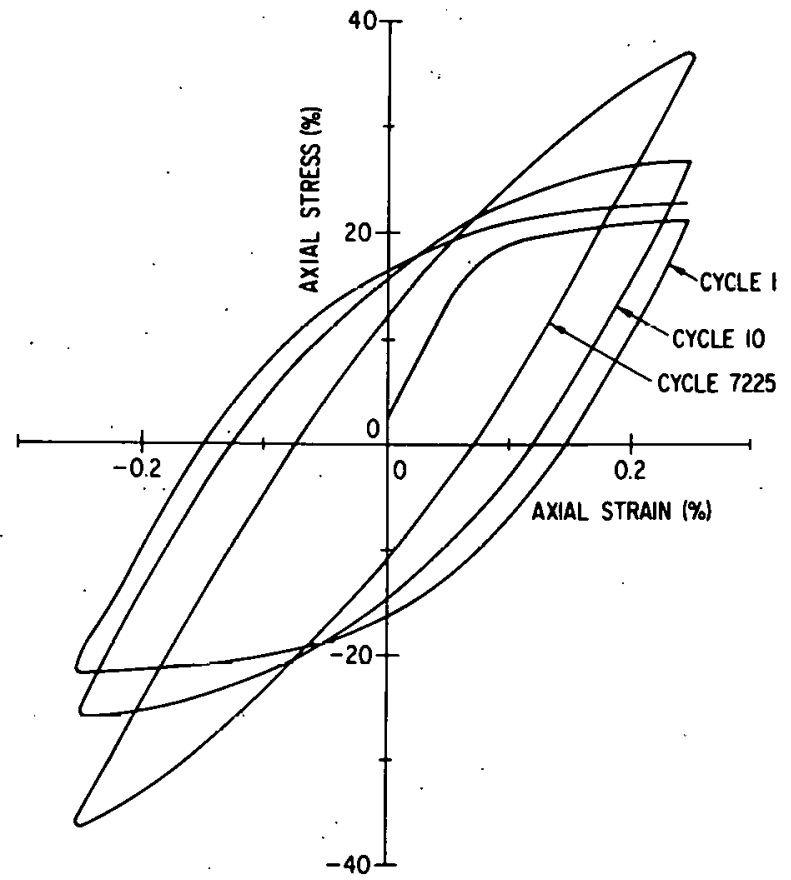

Fig. 13. Hysteresis Loops for Test No. 1001. ( $\mathrm{p}=1100 \mathrm{psi}$; hold time $=0$.$) Neg. No.$ MSD-66244.

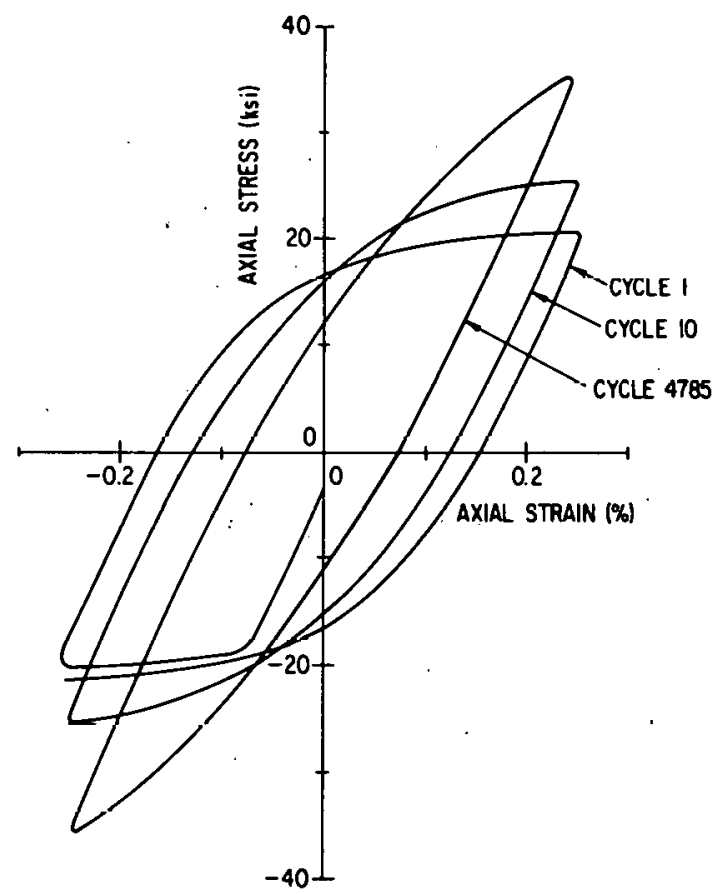

Fig. 15. Hysteresis Loops for Test No. 1044. ( $p=1100 \mathrm{psi}$, hold time $=0$. ) Neg. No. MSD-66242. 


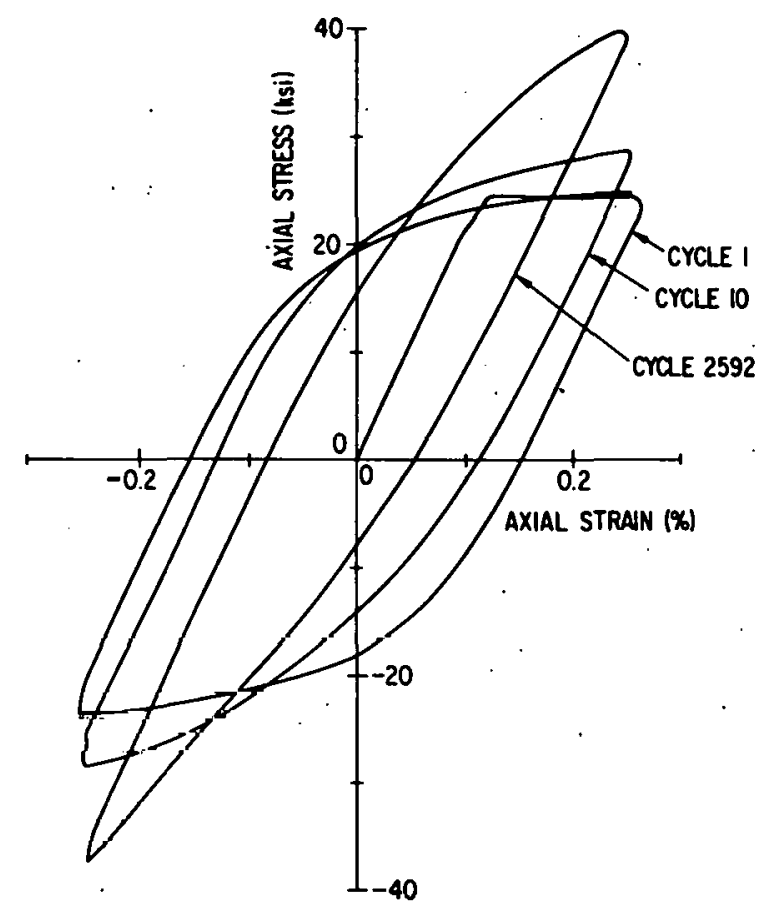

Fig. 16. Hysteresis Loops for Test No. 1024. ( $\mathrm{p}=1100 \mathrm{psi}$, hold time $=1$ c.) Neg. No. MSD-66259.

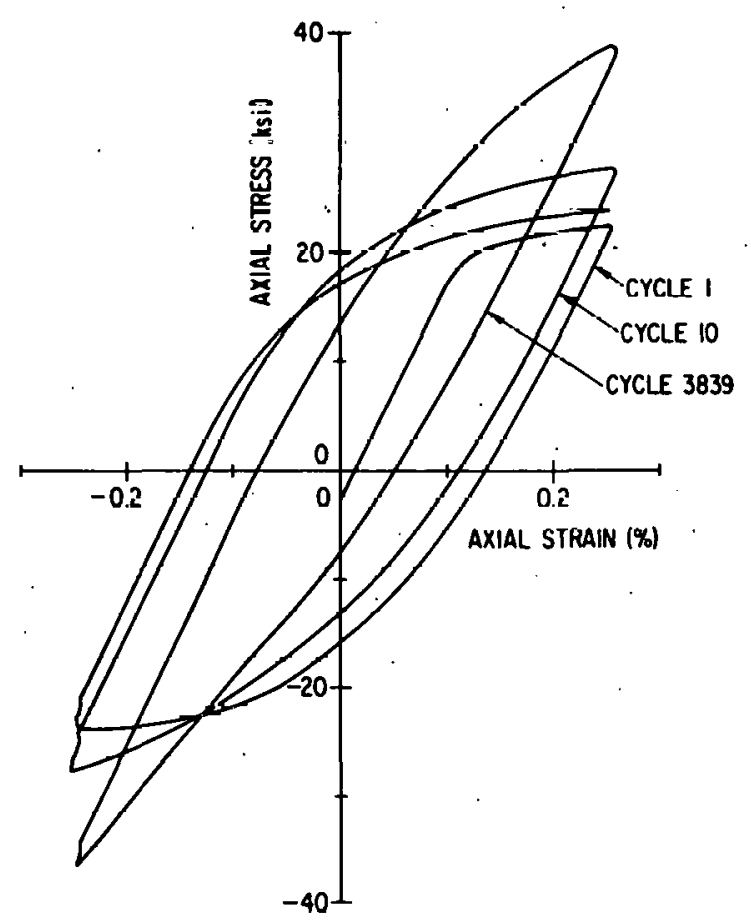

$\mathrm{X}$ Fig. 18. Hysteresis Loops for Test No. 1049. ( $\mathrm{p}=1100 \mathrm{psi}$, hold time $=1 \mathrm{~T}$.) Neg. No. MSD-66257.

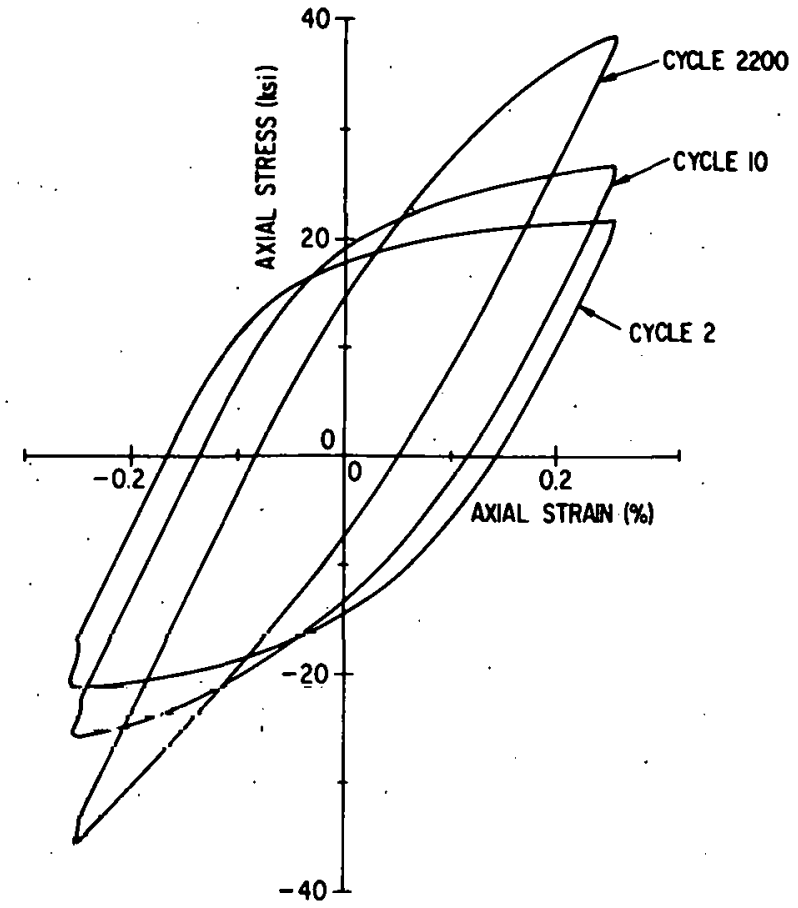

Fig. 17. Hysteresis Loops for Test No. 1033. ( $\mathrm{p}=1100$ psi, hold time $=1 C_{.}$) Neg. No. MSD-66251.

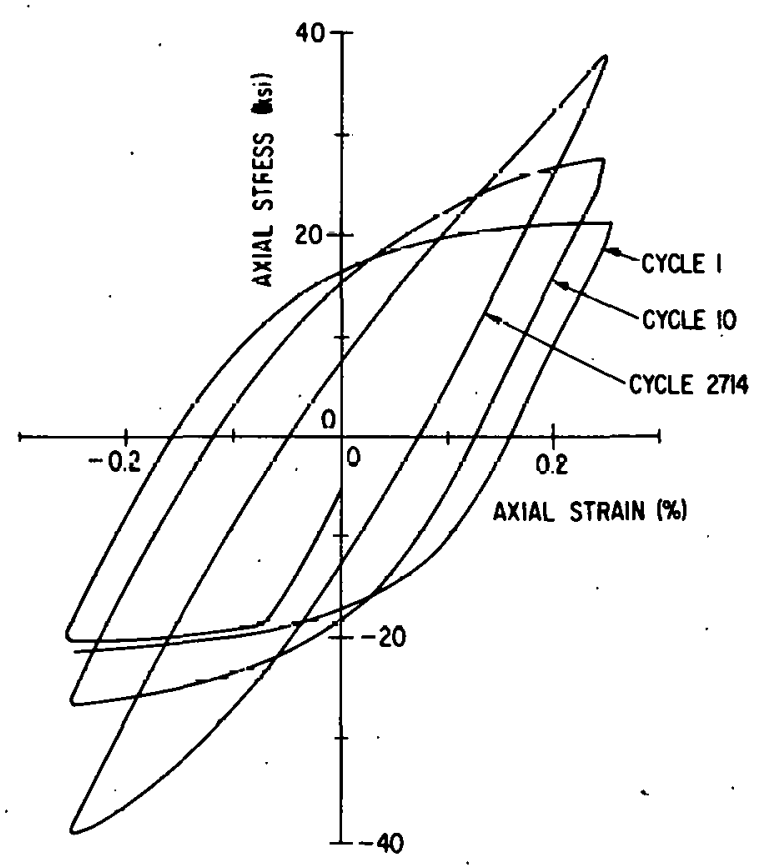

Fig. 19. Hysteresis Loops for Test No. 1038. ( $\mathrm{p}=1100 \mathrm{psi}$, hold time $=1 \mathrm{~T}$.$) Neg.$ No. MSD-66245. 


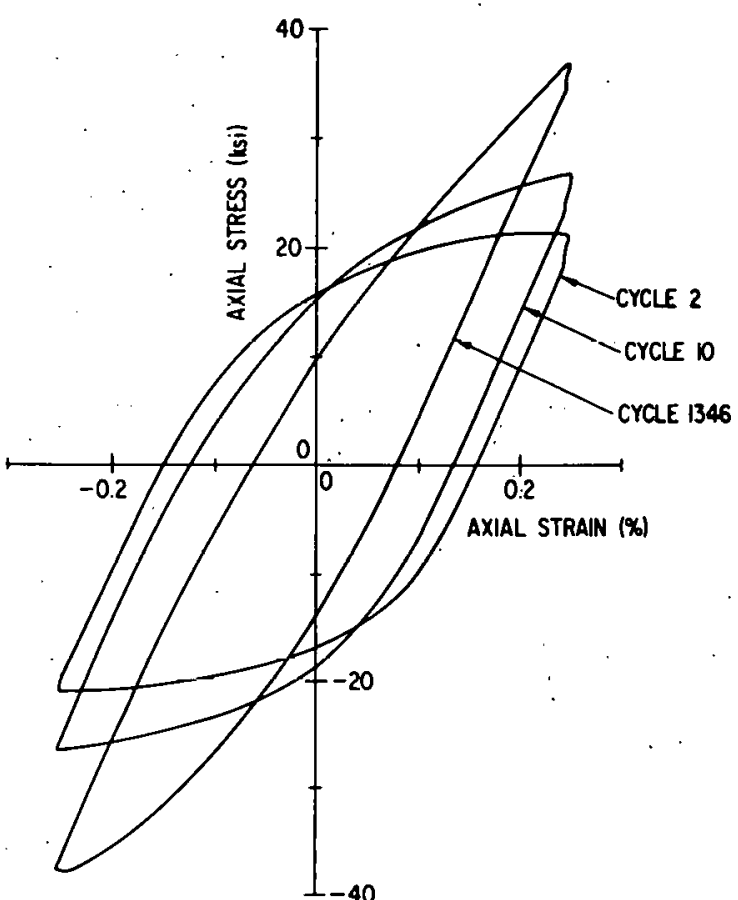

Fig. 20. Hysteresis Loops for Test No. 1041. ( $p=1100$ psi, hold time $=1 \mathrm{~T}$.) Neg. No. MSD-66260.

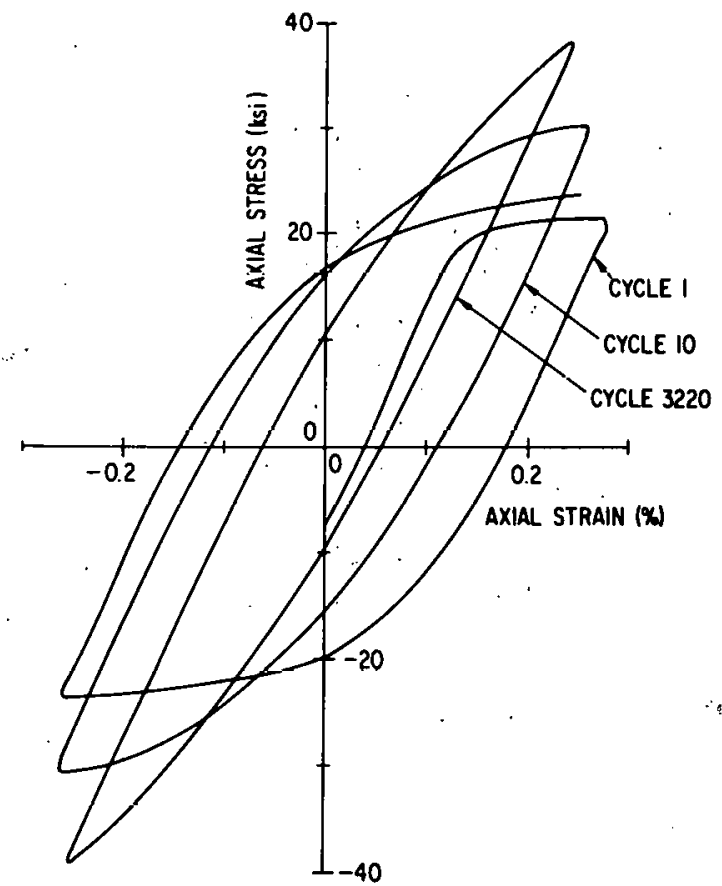

Fig. 22. Hysteresis Loops for Test No. 1059: $\quad(p=2000$ psi, hold time $=0$. ) Neg. No. MSD-66253.

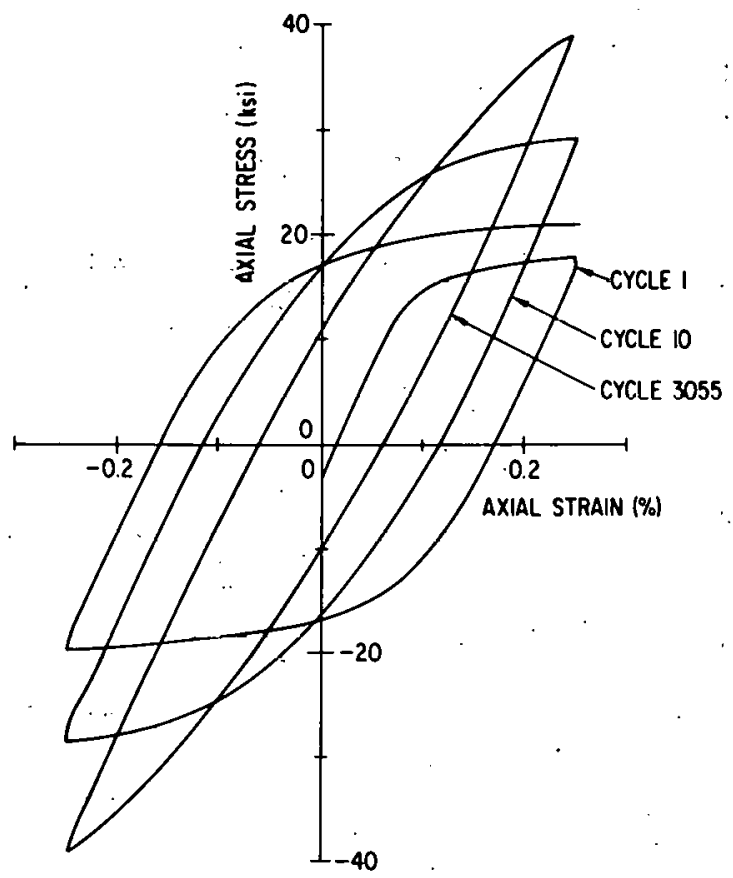

Fig. 21. Hysteresis Loops for Test No. 1031. ( $p=2000$ psi, hold time $=0$. ) Neg. No. MSD-66243.

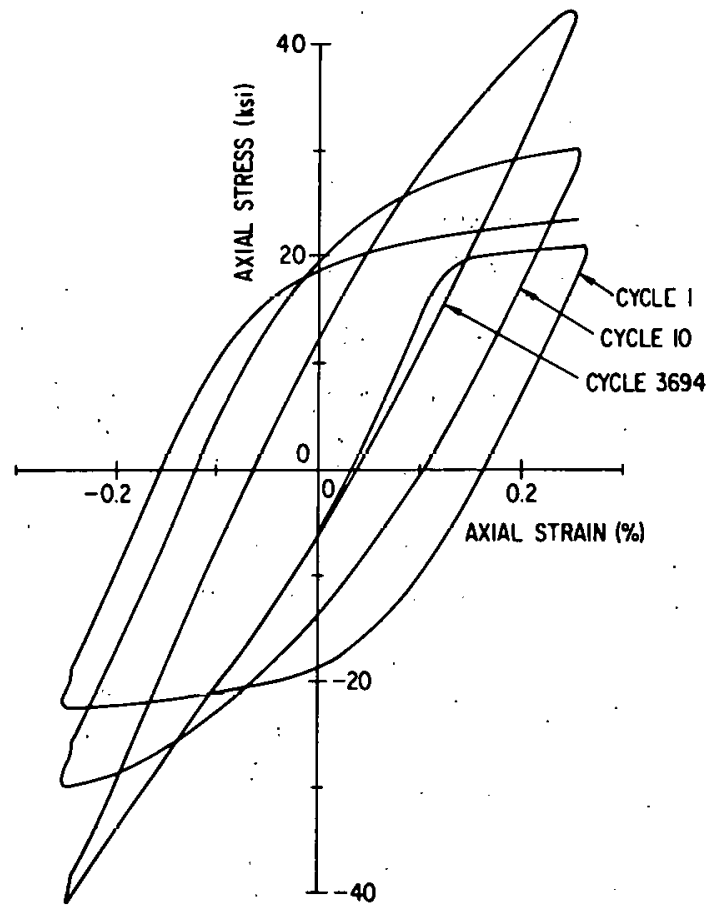

Fig. 23. Hysteresis Loops for Test No. 1050. $(\mathrm{p}=2000 \mathrm{psi}$, hold time $=1 \mathrm{C}$. ) Neg. No. MSD-66246. 


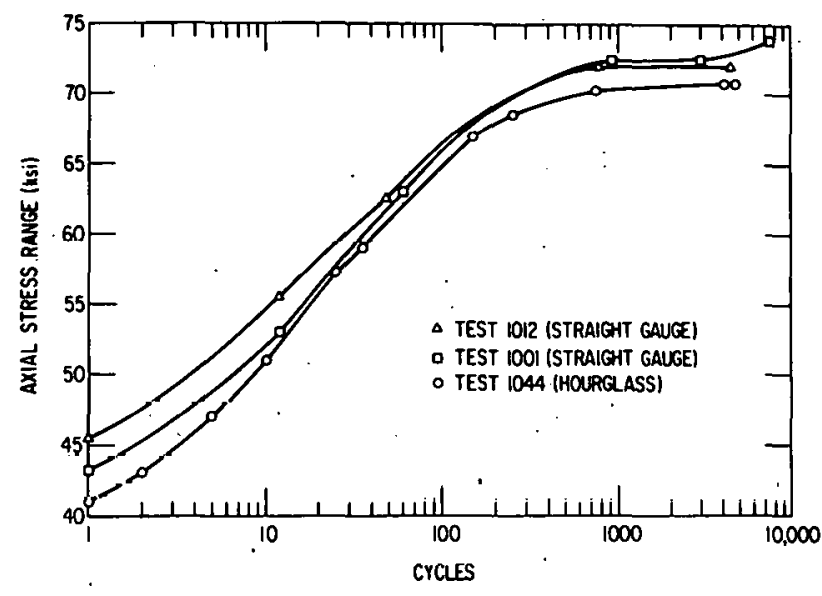

$\mathrm{xXX}$

\section{Fig. 24}

Comparison of Axial Hardening Rate for Straight-gauge and Hourglass Specimens. Neg. No. MSD-66256.

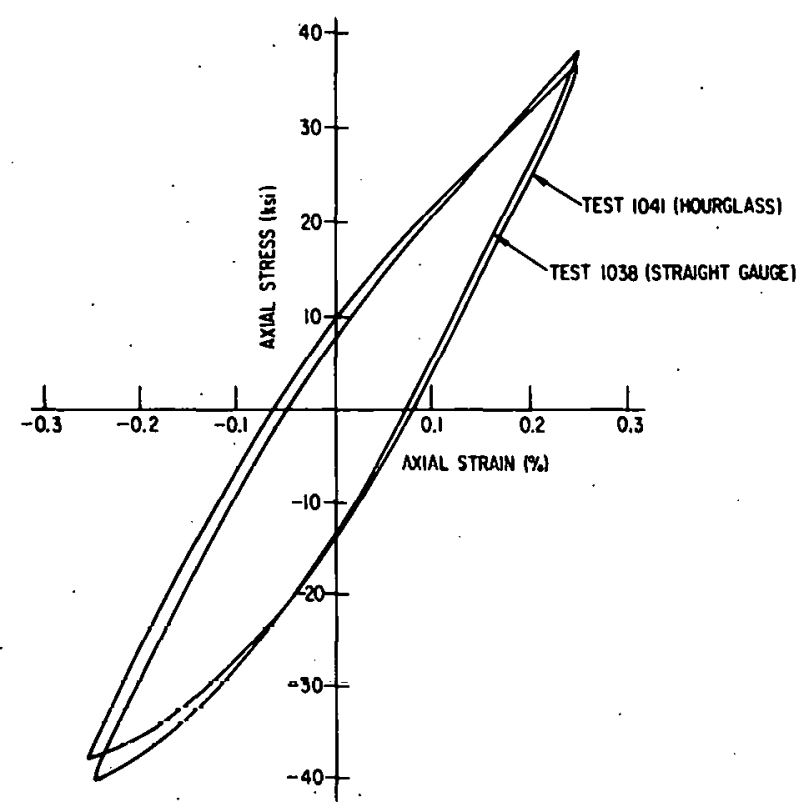

Fig. 25

Comparison of Hysteresis-loop Shapes for Straight-gauge and Hourglass Specimens. ANL Neg. No. 306-79-119.

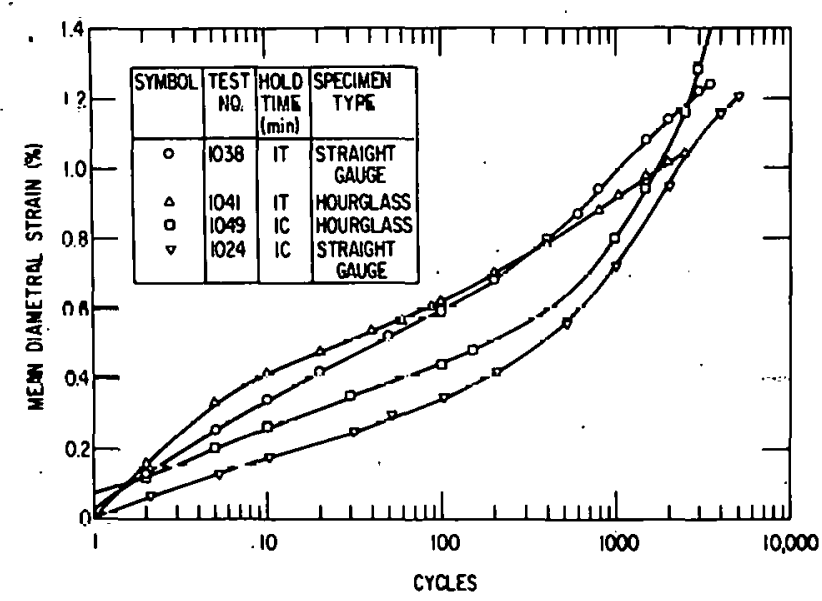

Fig. 26

Comparison of Diametral Ratchetting Behavior of Straight-gauge and Hourglass Specimens. Neg. No. MSD-66249.

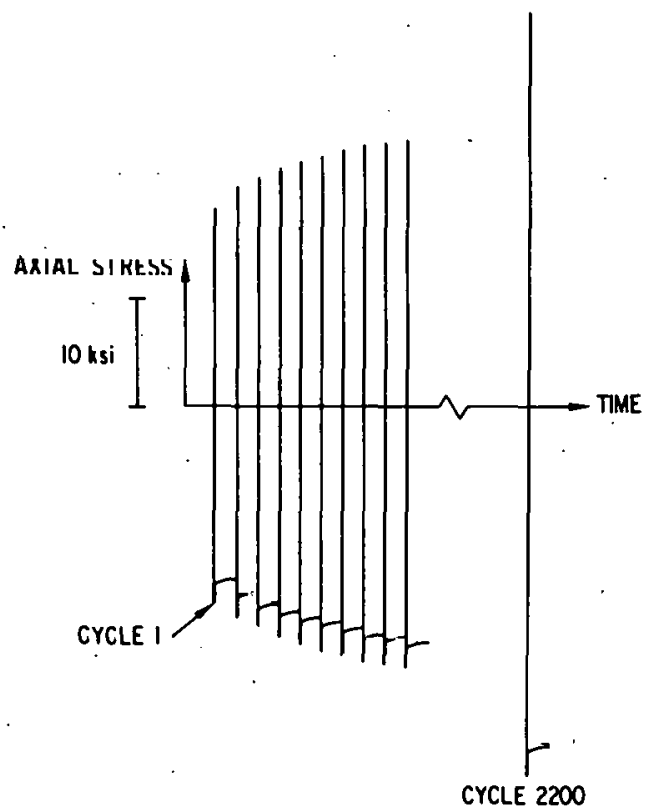

Fig. 27

Stress-relaxation Behaviour for Test No. 1033. Neg. No. MSD-66239. 


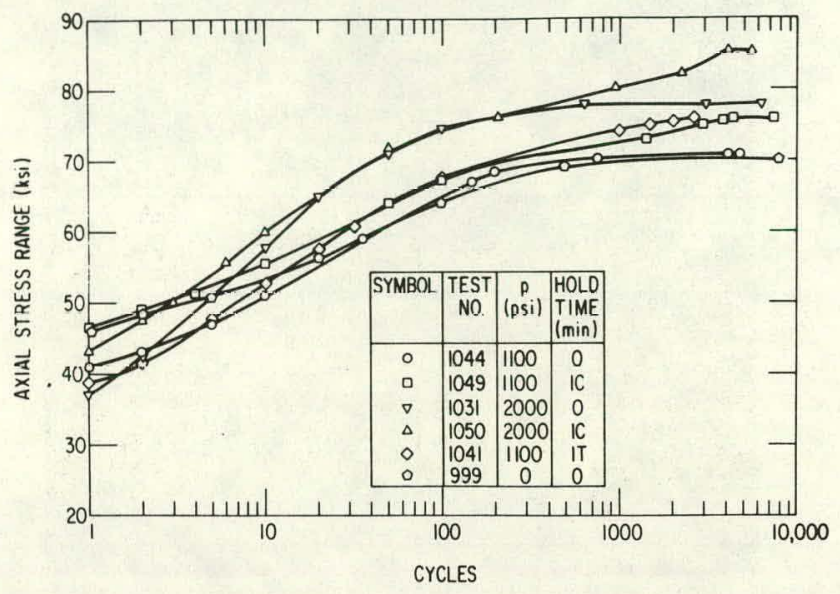

Fig. 28. Effect of Internal Pressure on Axial Stress-hardening Rate. Neg. No. MSD-66254.

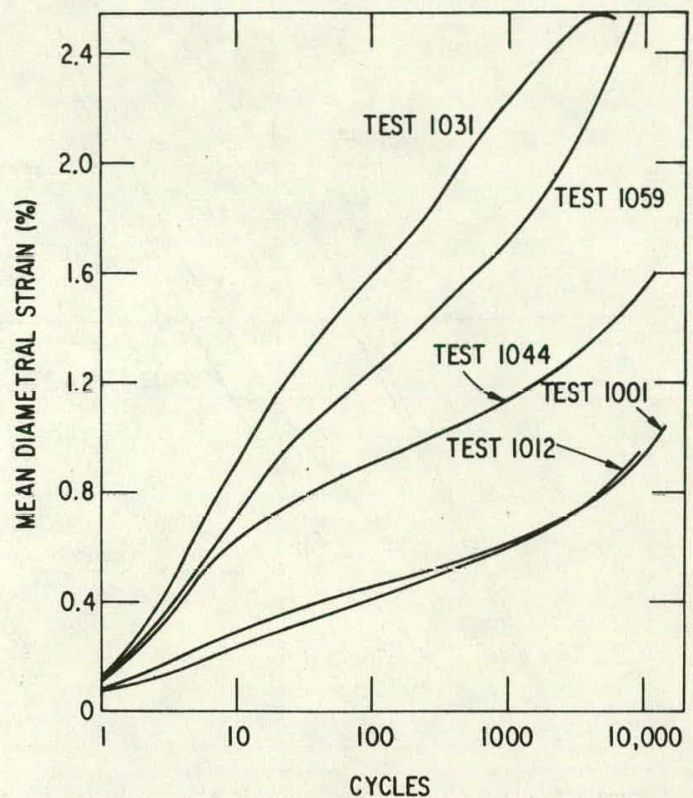

Fig. 29. Effect of Internal Pressure on the Diametral Ratchetting. Neg. No. MSD-66240.

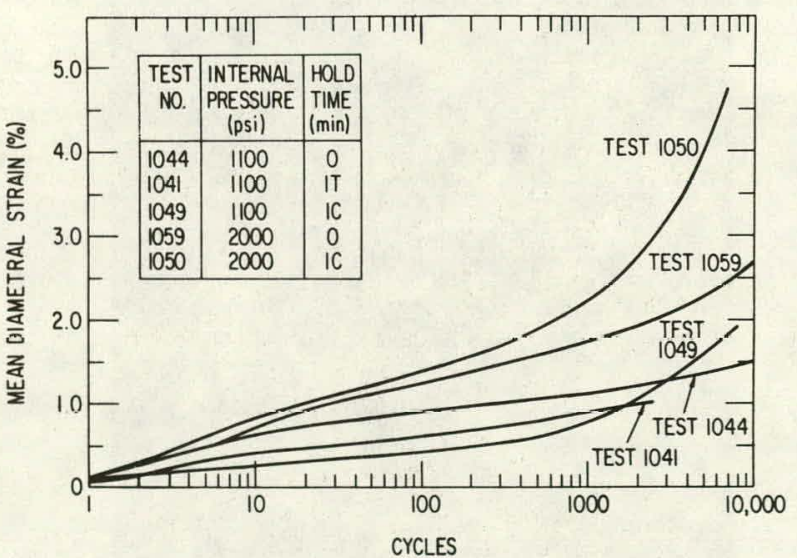

Fig. 30. Plots of Diametral Ratchetting vs Cycles. Neg. No. MSD-66250.

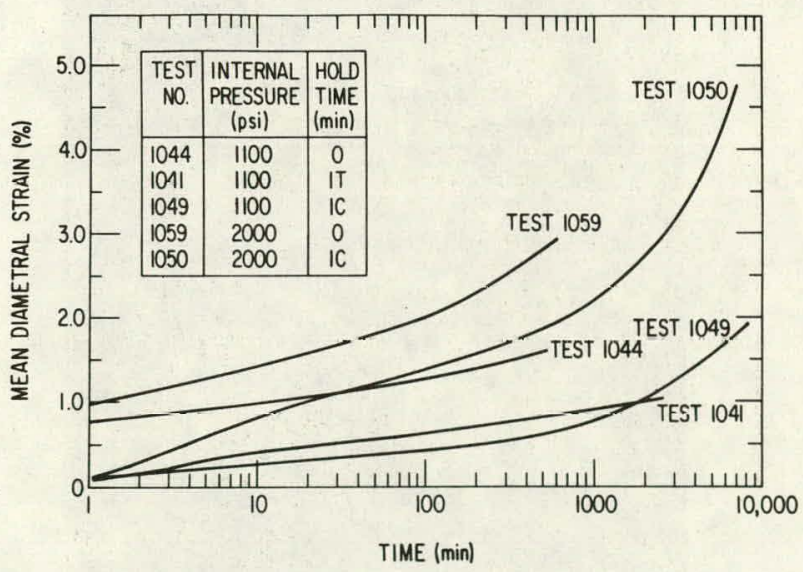

Fig. 31. Plots of Diametral Ratchetting vs Time. Neg. No. MSD-66255. 


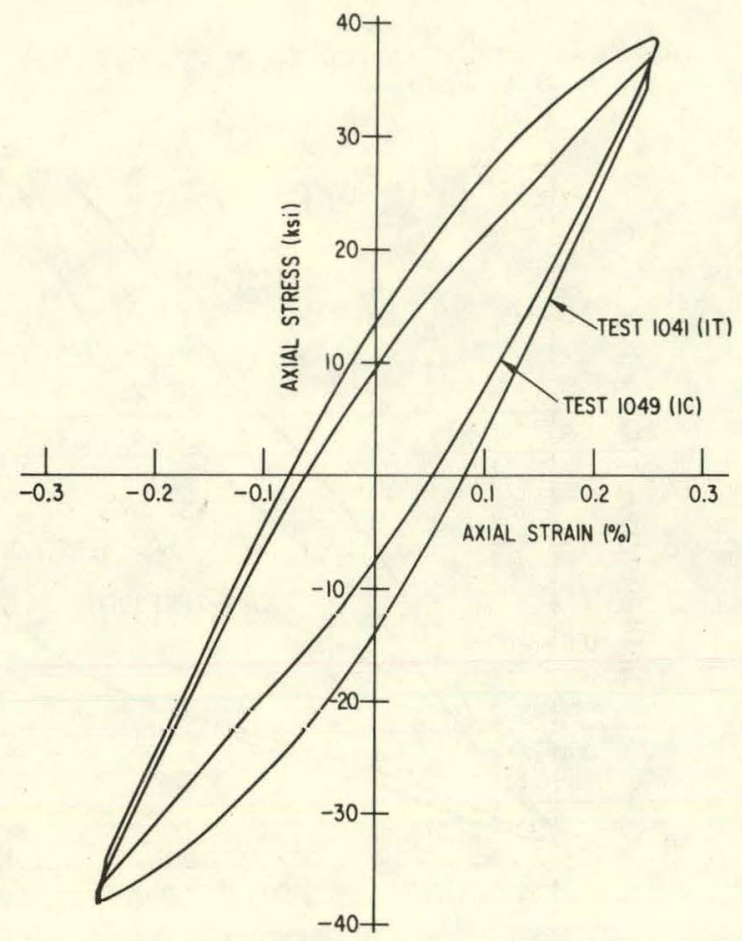

Fig. 32. Hysteresis Loops for 1-min Tensile and 1-min Compressive Hold-time Tests. ANL Neg. No. 306-79-121.

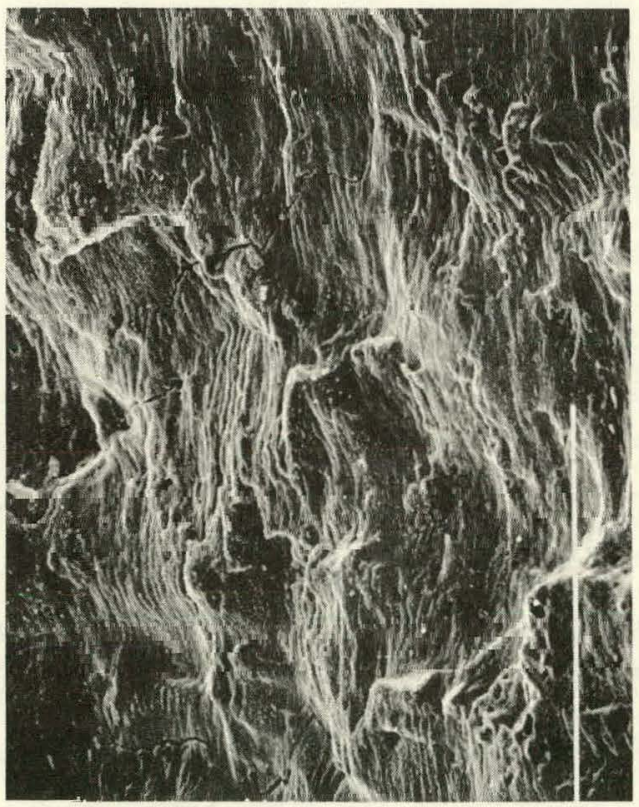

Fig. 34. Scanning Electron Micrograph of the Fractured Surface of Test No. 1033. Neg. No. MSD-66262.

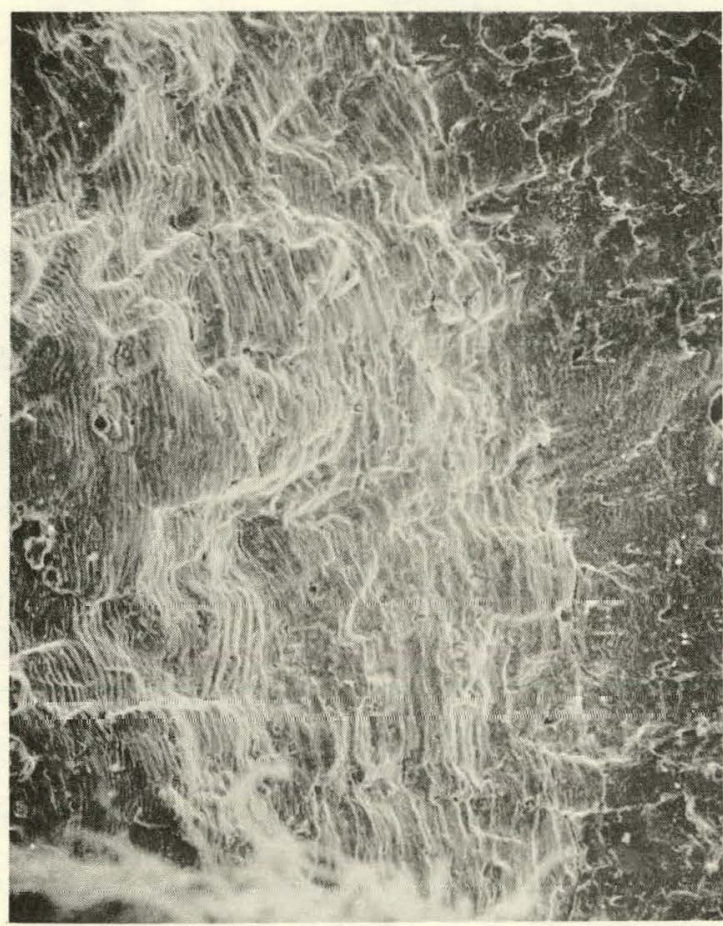

Fig. 33. Scanning Electron Micrograph of the Fractured Surface of Test No. 1044. Neg. No. MSD-66263.

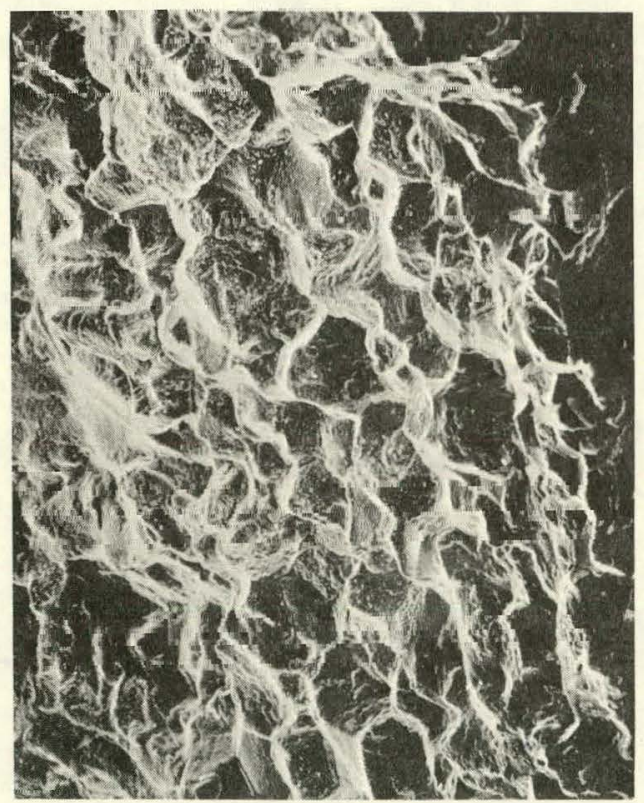

Fig. 35. Scanning Electron Micrograph of the Fractured Surface of Test No. 1041. Neg. No. MSD-66264. 
Distribution for ANL-79-33

Internal:

B. R. T. Frost

D. Busch

J. J. Roberts

M. Gorman

E. J. Croke

W. W. Schertz

E. M. Stefanski (4)

S. Majumdar (20)

A. A. Jonke

D. T. Raske

A. B. Krisciunas

P. S. Maiya

ANL Contract File

W. J. Shack

ANL Libraries (5)

W. Burke

TIS Files (6)

Externa 1:

DOE-TIC, for distribution per UC-62c (296)

Manager, Chicago Operations and Regional Office, DOE

Chief, Office of Patent Counsel, DOE-CORO

President, Argonne Universities Association

Materials Science Division Review Committee:

E. A. Aitken, General Electric Co., Sunnyvale

G. S. Ansel1, Rensselaer Polytechnic Inst.

R. W. Balluffi, Massachusetts Inst. Technology

R. J. Birgeneau, Massachusetts Inst. Technology

S. L. Cooper, U. Wisconsin, Madison

C. Laird, U. Pennsylvania

M. T. Simnad, General Atomic

C. T. Tomizuka, U. Arizona

A. R. C. Westwood, Martin Marietta Labs. 